\title{
سمات الفيلم الاحتفالي
}

عباس علي عجيل

جامعة بغداد - كلية الفنون الجميلة عجلية
أ. أم.د علي صباح سلمان

جامعة بذاد - كلية الفنون الجميلة

(مُلَخَّصُ الَبَحث)

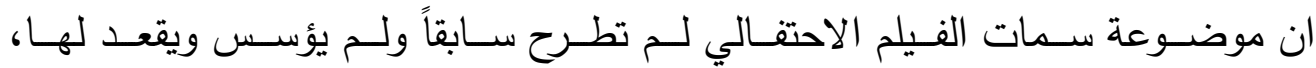

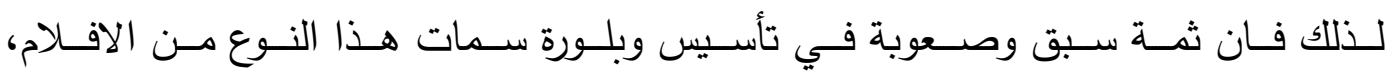

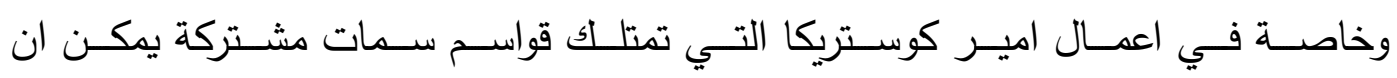
نســيها الاحتفاليـة والتـي تختلـف عـن الحكواتيـة او الفرجـة او الكرنفاليـة، علـى الـرغم

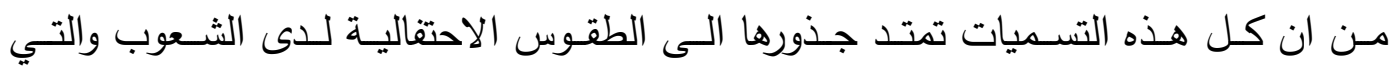

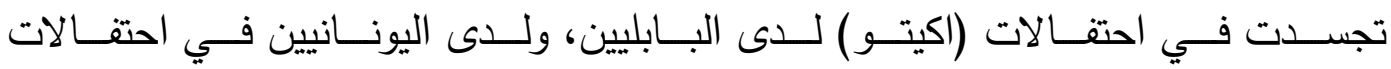

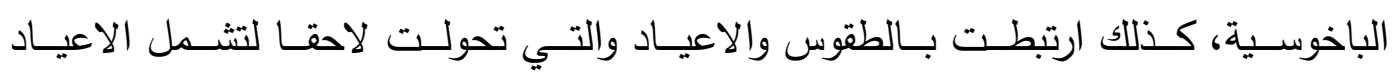

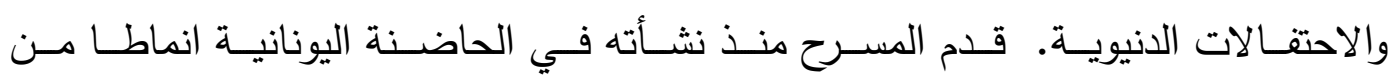

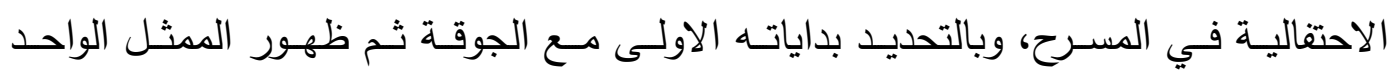

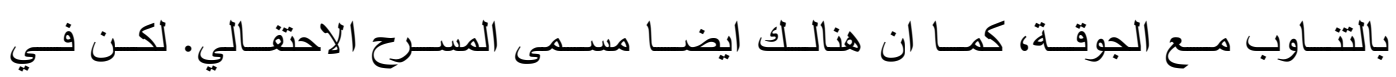

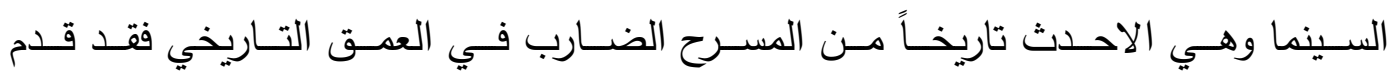
العديد من المخرجين افلاما تحمل سمات الاحتفال والحكواتية والفرجة والكرنفالية.

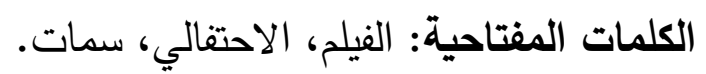
الفصل الاول الاطار المنهجي

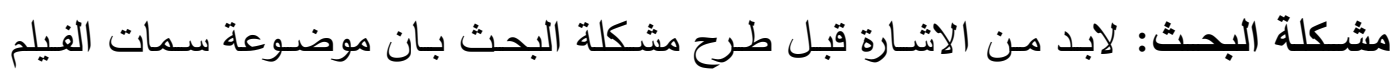

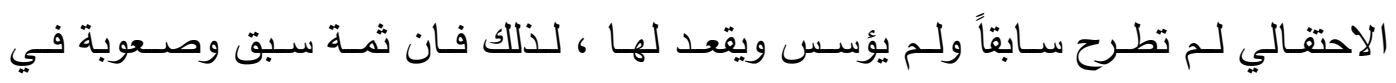

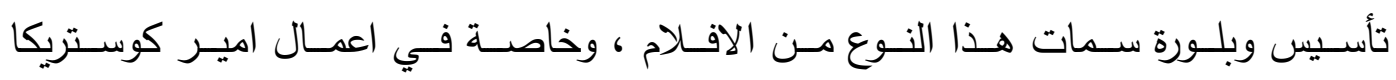

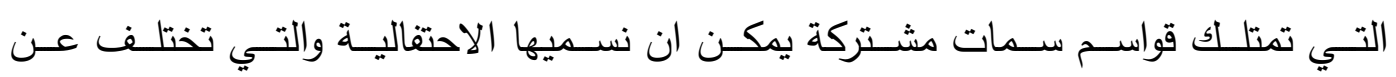

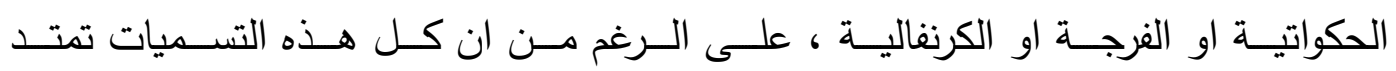

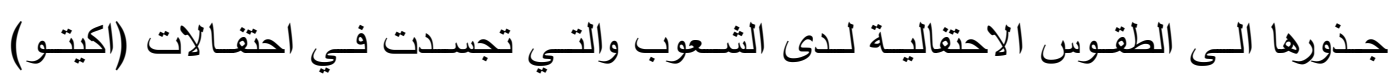

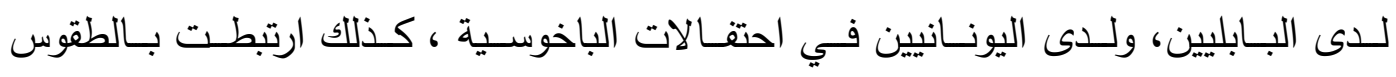

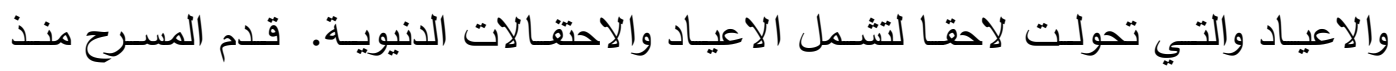

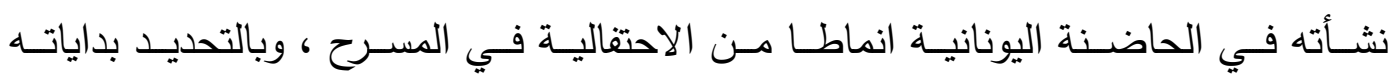

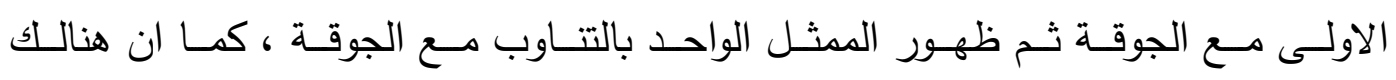

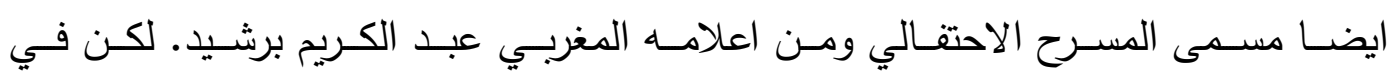




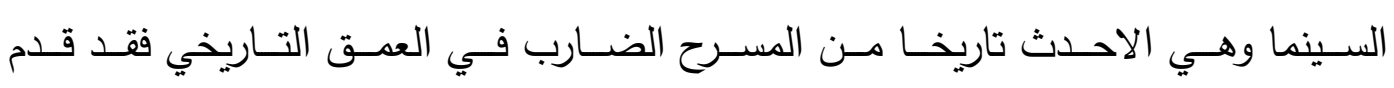

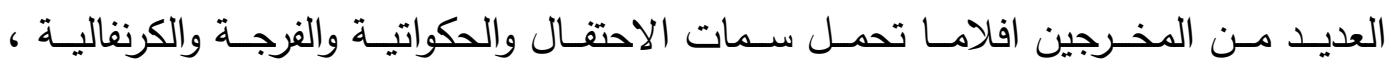
ولعـل اكثرهم وضـوحا في حمـل مســى المخـرج الاحتفـالي هـو " انطونيـوني" و" اميـر

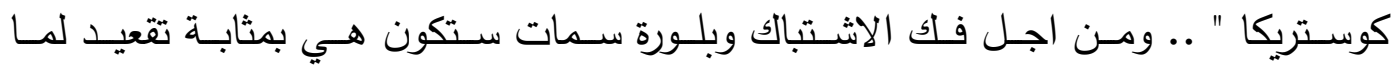
اسميناه الفيلم الاحتفالي وعليه فان مشكلة البحث تتبلور بالفرضية الاتية :

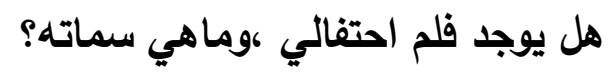

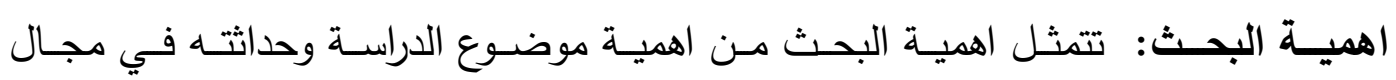

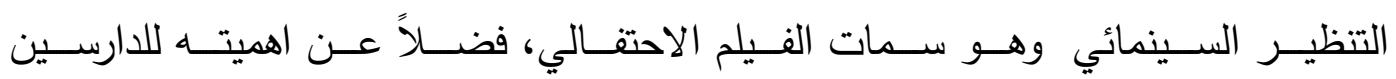

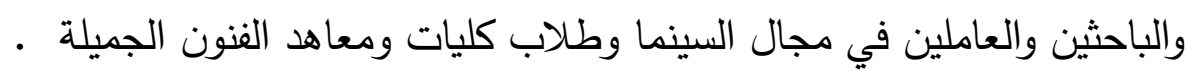
اهداف البحث: يهدف البحث الى التعرف على سمات الفلم الاحتفالي .

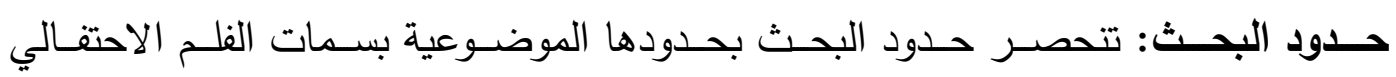
للدخرج (امير كوستريكا) في صربيا للعام 1990. تحديد المصطلحات

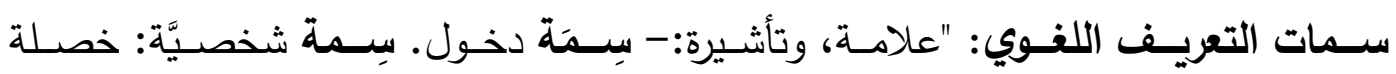

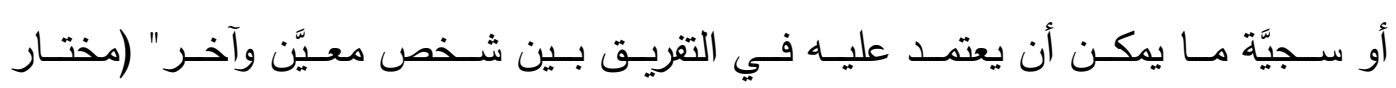

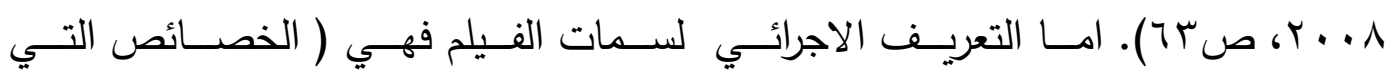

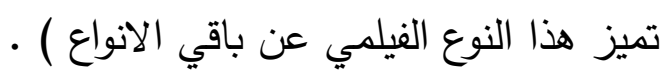

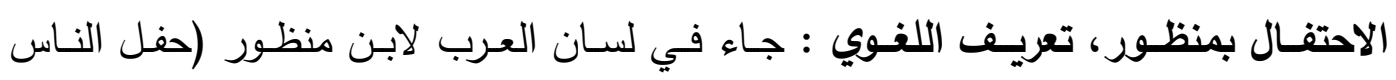

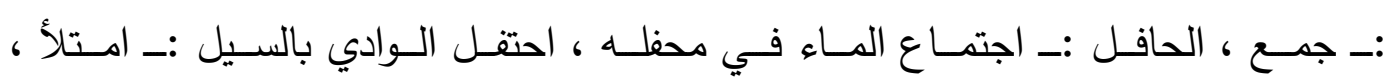
احتفل القوم :. اجتمعوا واحتشدوا ، والتحفل :. التزين ).

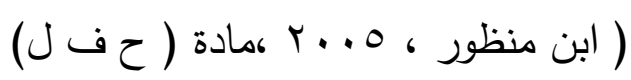

التعريـف الاصــلاحي: في المعجم المسـرحي فيثـير الـى انهـا مـاخوذة مـن اللاتينيـة

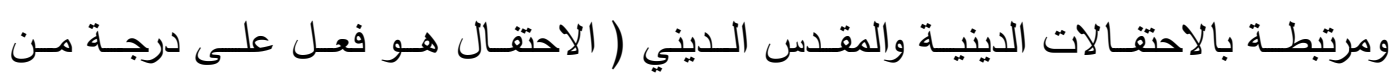

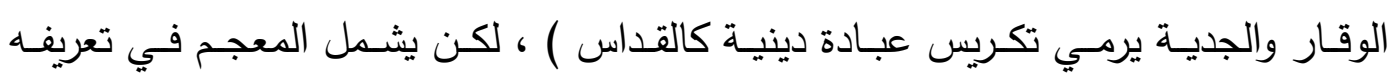

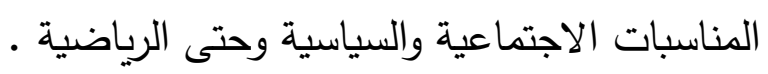

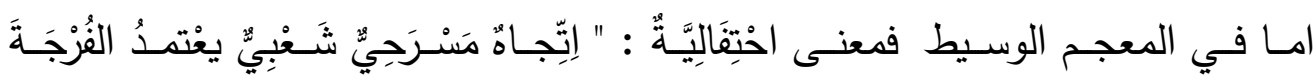

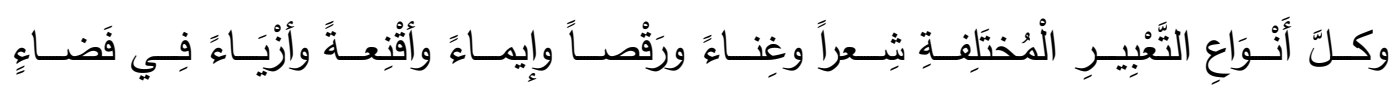

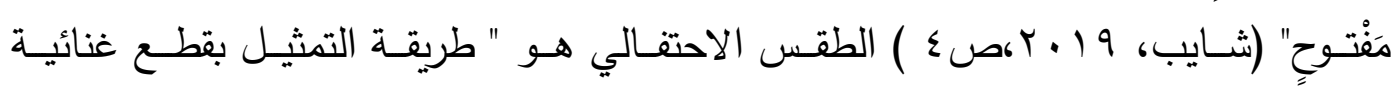

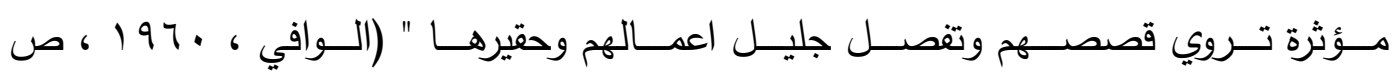


(الاحتفـال هـو تجمـع بشـري تمـارس فيـه طقـوس سـواء دينيـة او اجتماعيـة يتخللهـا

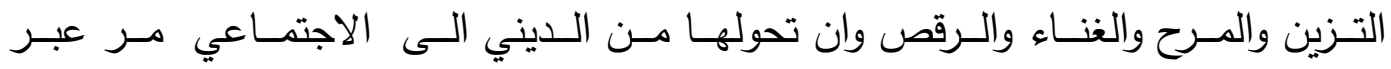
عصـور عديـدة ليمثل بالتـالي طقوس الثـعوب والتعبيـر عـن ثقافاتهـا الثـعبية) ، حيـث " تتـألف مـن خـزين عـام مـن العـادات والتقاليـــ والمعتقـدات والمفـاهيم واللغــة والاسـاطير والقوانين وقواعد السلوك " (الياس ، 1997 19 ، ص ب). التعريـف الاجرائسي: لفـيلم الاحتفــالي هـــ ( فـيلم طقوسـي جمعسي لــه مظــاهر النزعـة الاحتفاليـة مـن حيـث الغنـاء والـرقص والزفـاف عبـر سـرد حكـائي سمعبصـري

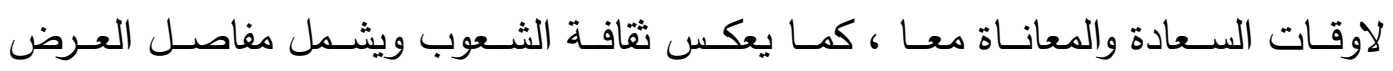
البصري مزج الفنطازيا والغرابة والحلمية والواقعية السحرية والمفارقات) الاطار النظري

المبحث الاول :اشتغال عناصر اللغة السينمائية في الفيلم الاحتفالي ان المبحـث يرتكـز الـى تأسيسـات تتخــذ مسـارين عمـودي وافقـي. العمـودي هـو البنـى الاسـلوبية والجماليـة والثـكل الفيلمسي الاحتفـالي عبـر عناصـر اللغـة السـينمائية ،

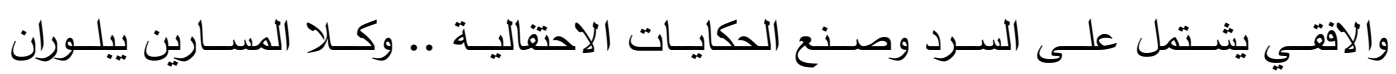
طقـوس العلاقـة الاحتفاليـة بـين المشـاهد والفــم ـ تتجســـ المشــاركة الجماعيـة للمشـاهدة فـي الصـالات التـي هـي بمثابـة طقـس احتفــالي يمثـل كـل الطقـوس الاحتفاليـة لـدى الثـعوب الافـلام وبـاختلاف اسـاليبها ـ لكن مـا الــي يجعلنـا نـذهب الـى تحديــ سـمات

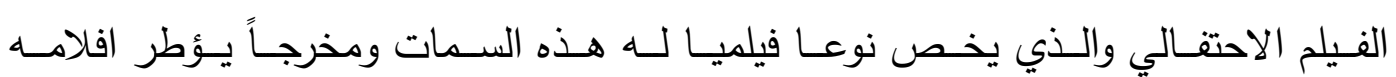

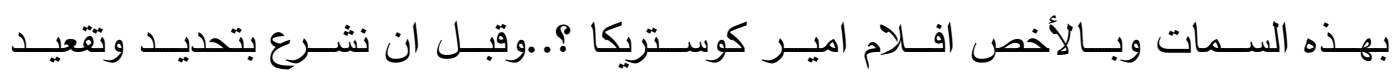
سـمات الفـيلم الاحتفـالي فأننـا نشـير الـى فضـاء الفـيلم الـذي يتشـكل مـن (مستن حكـائي ومبنـى حكـائي ) حسـب طروحسات توماشفسكي ، كمـا يتشـكل مـن بنيـة السـرد وبنيـة

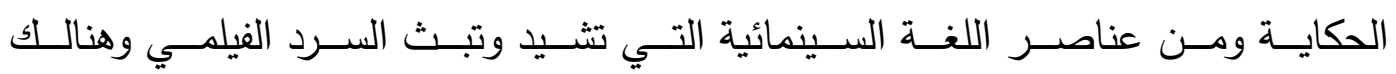

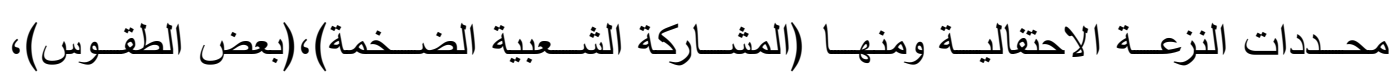
(الاثـارة والحماسـة)،(النزوات كغرائبيـة ومفارقـة ومولـدة للكوميـديا والفنطازيــا)، (الـرقص والغنــاء كمتـنفس عـن المكبوتات)،(انتهـاك التـابوات عبـر عربـدة مجنونـة تعـج بالصـخب

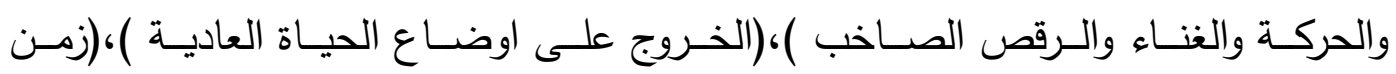
الانفعـالات الحـادة والتحــول الكيـاني بفكـرة التجديـد والصـيروة )، (تتضــمن احتفـالات

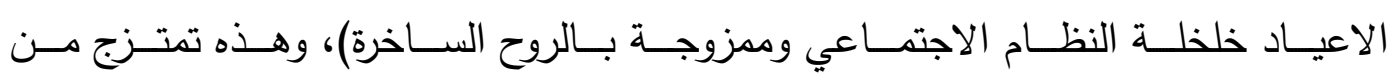

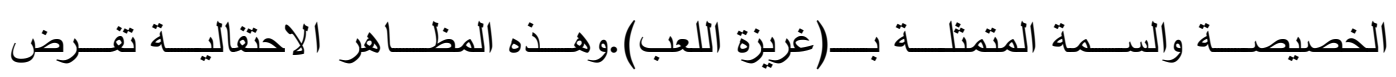

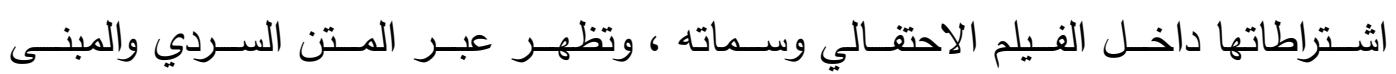




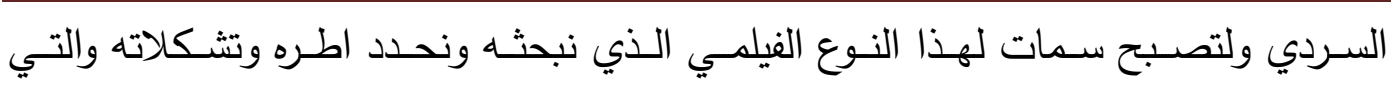

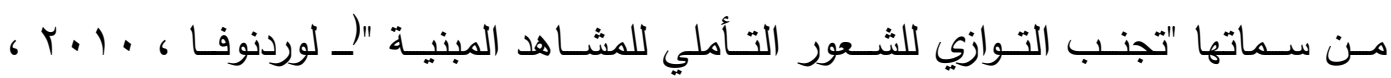

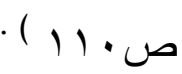

عناصــر اللغـة السـينمائية التـي تثـيد المبنـى الاحتفــالي للفـيلم وتمنـــهـ ســاته

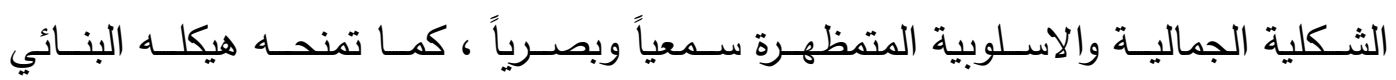

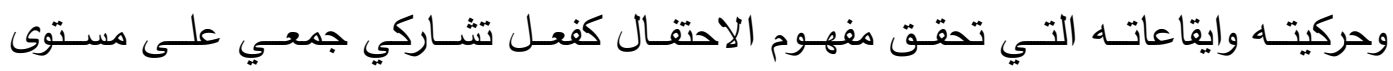
اللاوعي الجمعي وكفعل اسلوبي سينمائي :

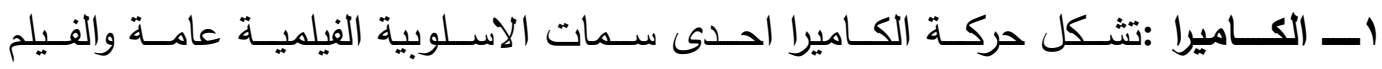

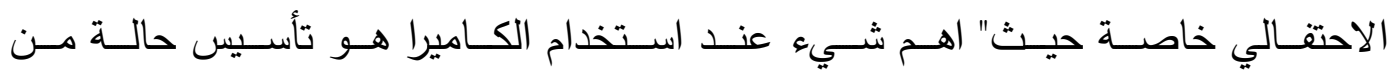

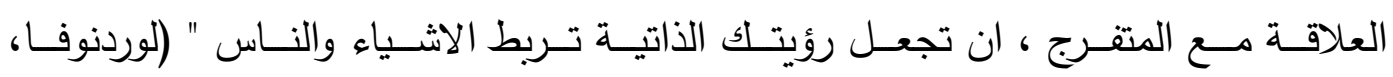

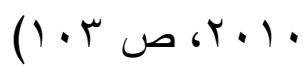

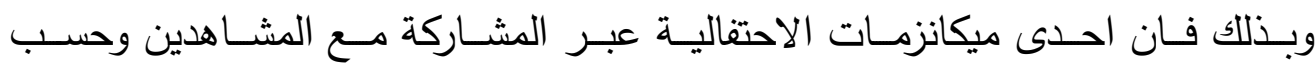

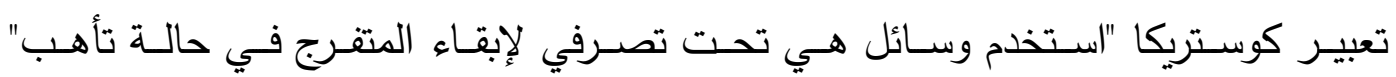

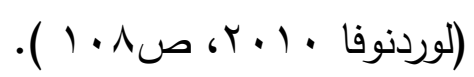

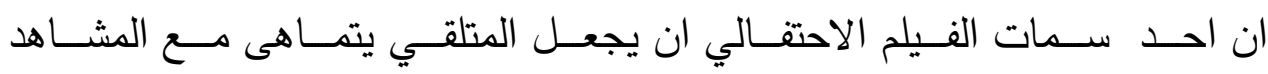

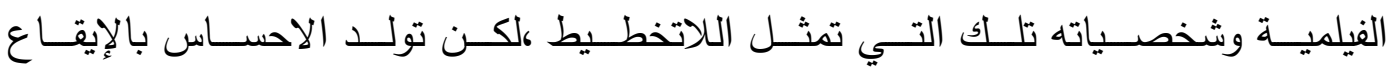

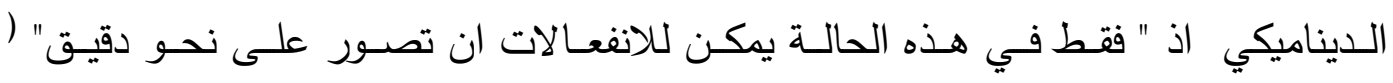

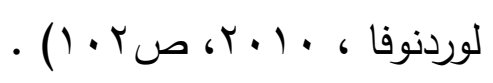

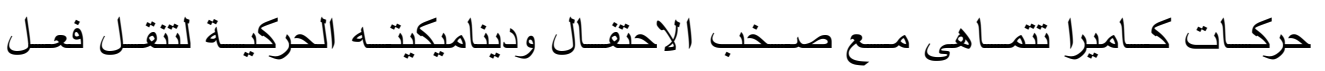

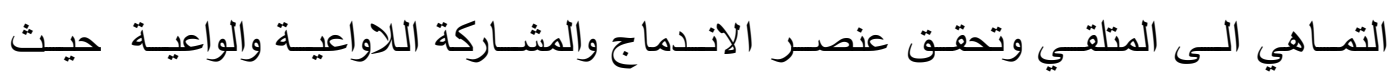

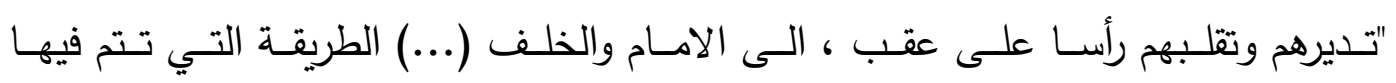

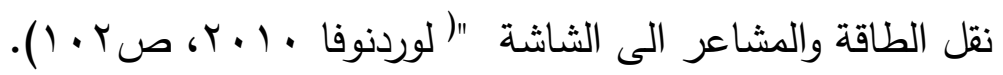

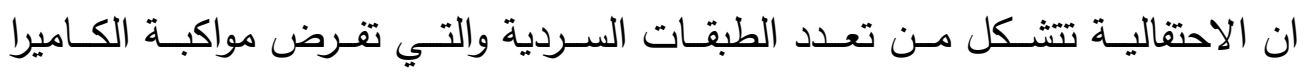

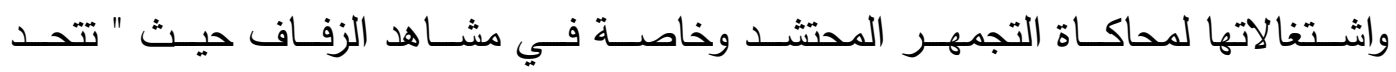

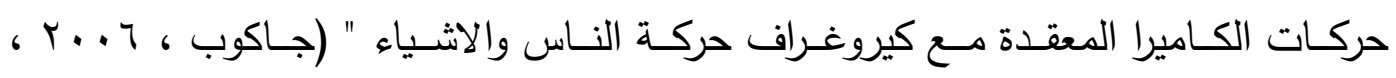
ص (9) (9) (9) (9)

ومسـن خصـائص الكـاميرا الاحتفاليـة يتمثـل باســتخدام حركـات الكـاميرا الــائرة

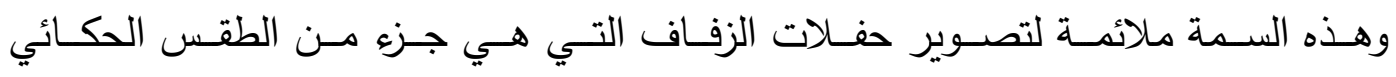

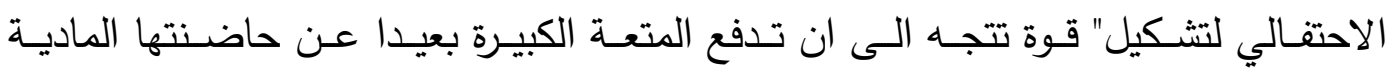

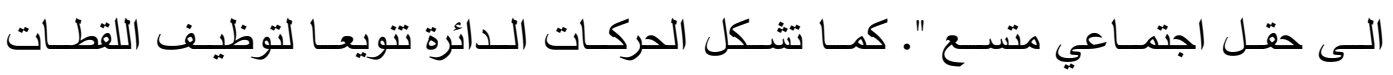


الطويلــة التـي تؤسـس لفضــاء الاحتفــال وتتمظهـر ككـاميرا احتفاليــة والتـي " تتضـــن

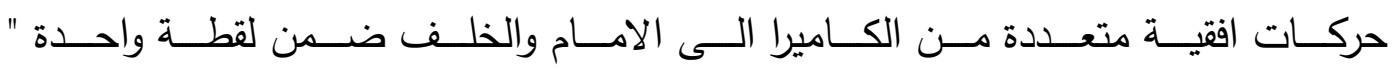

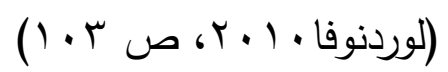

يكـون المصـاهرة بـين الكـاميرا الذاتيـة والموضـوعية سـمة داعمـة للاحتفـال حيــث "الانتقـال مـن الكـاميرا الموضـوعية الـى الذاتيـة ثـم العـودة الـى الموضـوعية، مـن كـاميرا ثابتـة الـى كـاميرا متحركـة تجعل المتفـرج شـاهدا ثم مسـاهما فيمـا يحدث، مجبـرا ايـاه ان

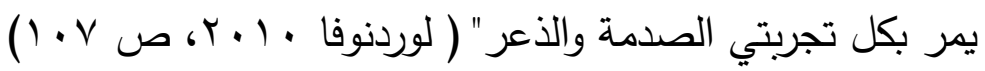

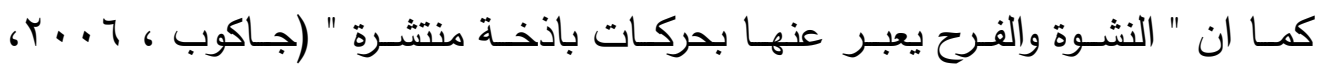

وكـذلك الحلميـة كسـمة مـن سـمات الفـيلم الاحتفــالي لكسـر سـلطة الواقـع واعـلاء

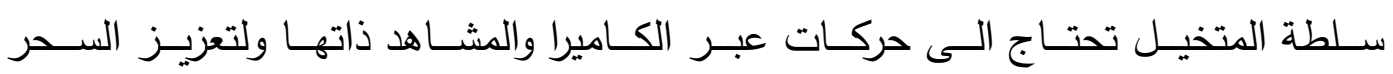
البصـري ، ويـتم تقـديم الانفتـاح الفضــائي، لان المشــاهد الكرنفاليـة عـادة تتشـكل مـن تجمعـات ولامركزيـة حركيـة مسـتمرة، تفـرض شـكل التكـوين البصــري المفتوح و "الابتعـاد عـن مسـرحة التكوينـات البصـرية وطرازيتهــا بمـا يـوحي بتكوينـات لا طرازيــة وغيـر رسمية بشبه تلقائية وغير قصدية" (جانيتي، (919 (، ص مه 1).

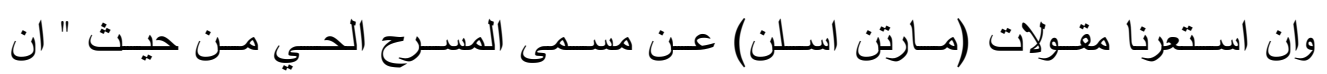
التـأثير المتقابـل ذا الثــعب الـثلاث فـي المسـرح الحـي (كمــا هـي التجربـة الجماعيـة للجمهـور ..وفي السـينما) عنصـر مهـم مـن عناصـر النفوذ الـدرامي ، ويقصـد بالثـعب الـثلاث هــي " تـأثير الجمهـور فـي الممثـل ، تــأثير الممثـل فـي الجمهـور، تـأثير الجمهور في الجمهور " (اسلن ،عدو 19 ، ص • • (1) ). وهـذه النزعـة لمقاربـة الاحتفاليـة الحيـة تـدفع باتجـاه توليـد الاحسـاس لـدى المتلقـي

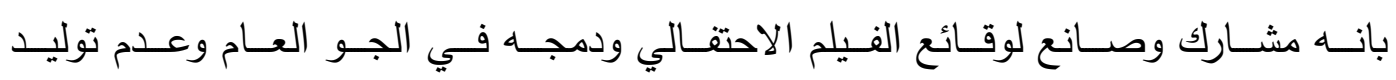
الاحسـاس لايـه بانـه داخـل صـالة عـرض سـينمائية. ان واحـدة مسن تشـكلات الاحتفـال والفـيلم الاحتفـالي هـو النـزوع الهرقيطيسيـ نسـبة الـى الفيلسـوف اليونـاني (هـرقليطيس)-

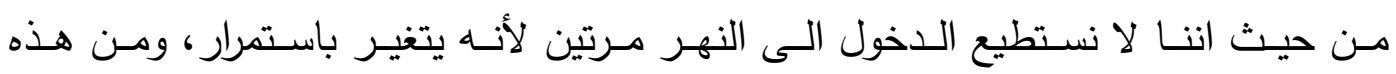
النزعـة يكـون الفـيلم الاحتفــالي متغيـر ودينـاميكي علـى كـل المسـتويات بمــا يثـكل كـإدراج دينـاميكي يتضــمن حركيـة المشـاهد الفيلميـة وحركـة الكـاميرا .تشـكل اسـتخدام النشـاط الحركي للكـاميرا ليلاحـق ويقـدم وبشـكل ابهـار بصـري تلـك السـرديات الثانويـة للفـيلم الاحتفـالي مـن حيـ "عـرض اسـتعراض مكثف للكـاميرا والحصـول على مسـتوى

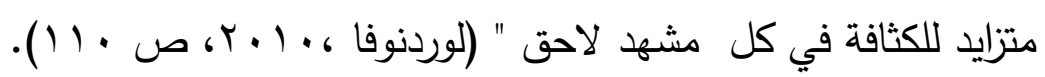


المـــؤثرات السمعبصـــرية :علـى مســتوى الاضــاءة فــان الحلــول الاضــائية والســرد الاضــائي ينحــاز الــى الاضــاءة ذات المفتــاح العـالي لكـن المصـــاهرة بـين النــوعين

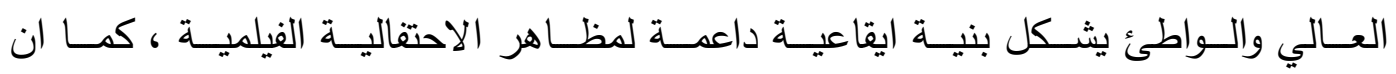

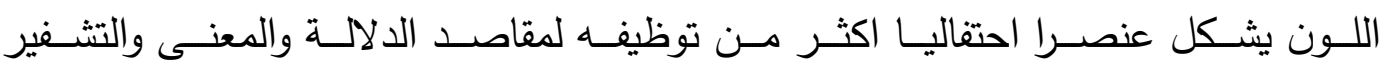

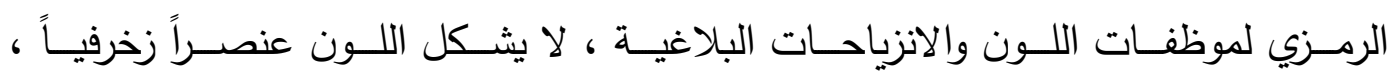

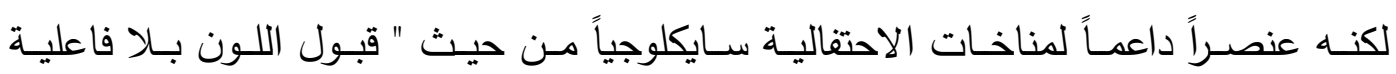

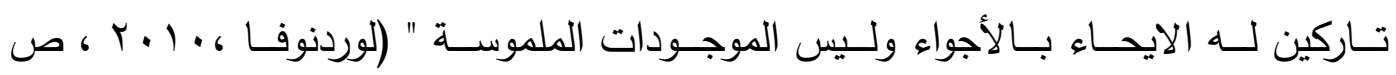
• 1 (1). كمــا ان اي محسـاولات لرفـع التشـوهات البصـرية الـى مسـتوى الرمـز لا يقــدم دعمــا للـروح الاحتفاليـة التي تفتـرض تقـديمها بطريقـة تحقـق الاعـلاء للجمـالي والمتعـة

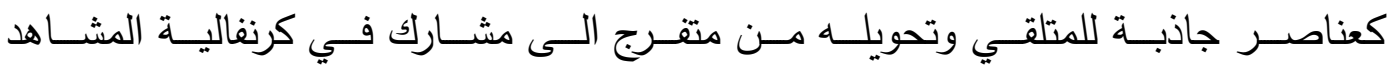

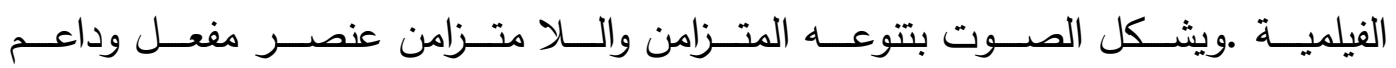
لديناميكيـة المشــاهد الاحتفاليـة، كمــا هـي الموسـيقى كمازلمــة ثابتــة لســمات الفـيلم

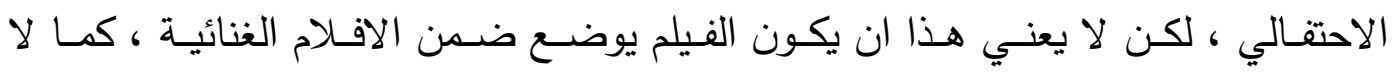

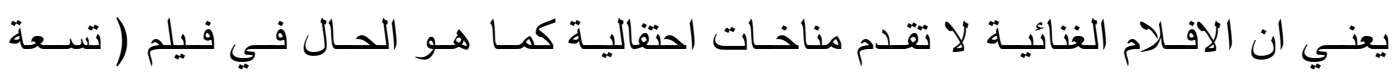
نساء، شيكاغو ) ( نـادي القطـن للمخـرج الامريكـي كوبـولا) ـ. الموسـيقى والغنــاء الفلكــوري مظهـر

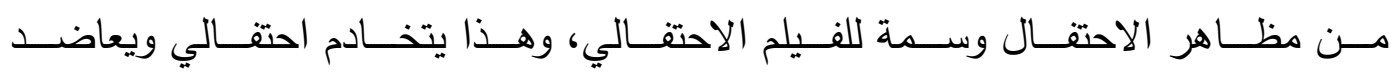
ديناميكيـة الفـيلم الاحتفـالي على مسـتوى تعـدد طبقـات الحبكـات وديناميكيـة عناصـر

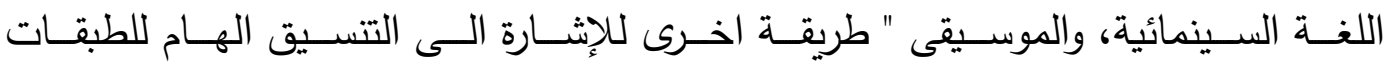

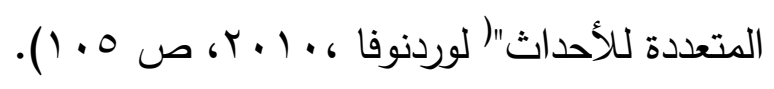
فلكلوريــة الفـيلم الاحتفــالي تتمظهـر عبـر الغنــاء والموسـيقى والازيــاء والـديكورات لتشـكل تتوعـا للفيلم الاحتفـالي ولا تحصـره بشـب محـد او بمخـرج محـدد ،بـل تمنحسه

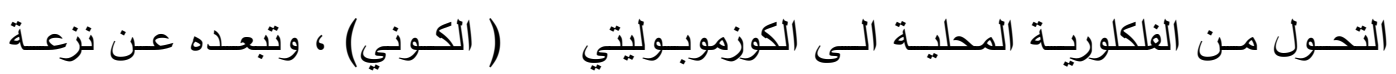

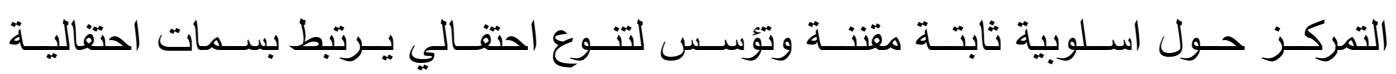
عامــة تتــوع بتــوع الثـعوب والاسـاليب والــرؤى التـي تعكس الـروح الاحتفاليـة لكـل شـعب مـن الثـعوب ، لكـن ثــة افـلام احتفاليـة تقـدم المحلـي الفلكلـوري بكـل عناصـره، او تذهب الى التاريخي والاسطوري لتقدمه. المونتــاج :مــا هـو المونتـاج الـذي يميـز الفـيلم الاحتفـالي بكـل بنائـهـ المغـاير وليخلـق ايقاعــا يشـكل سـمته؟، حيــث ان وظـائف المونتـاج تـــدرج ضـــن (الوظيفـة السـردية لإنتــاج وتتظـيم الحكايـة، الوظيفـة الدلاليــة التـي تشـكل مجموعـة الافكــار والمفــاهيم، 


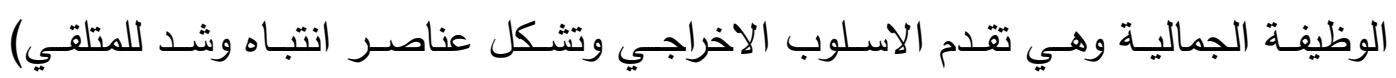

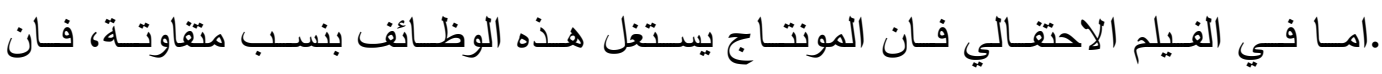

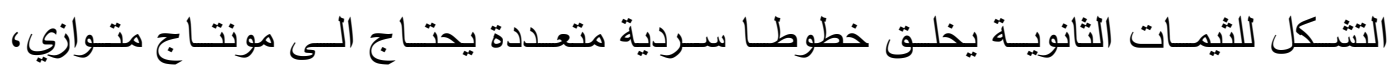

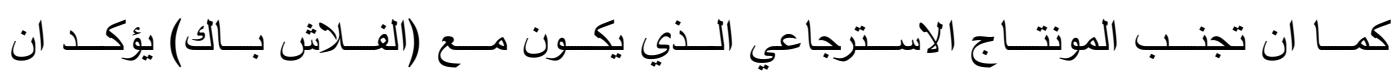

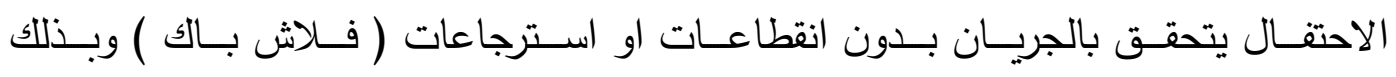

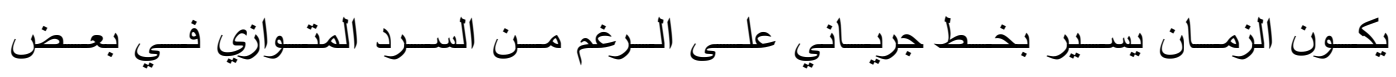

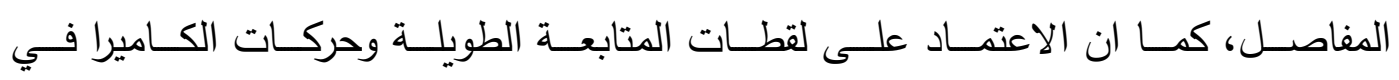

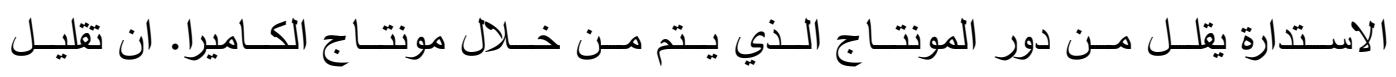

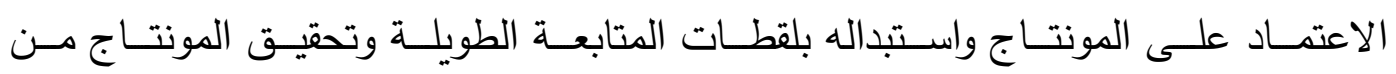

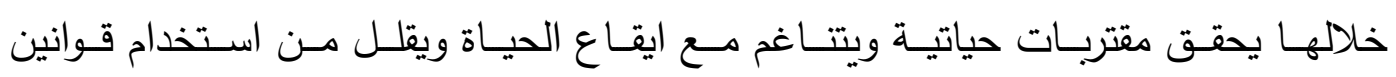

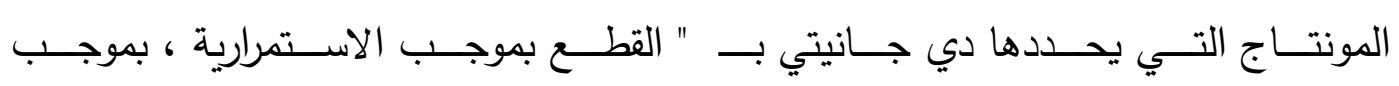

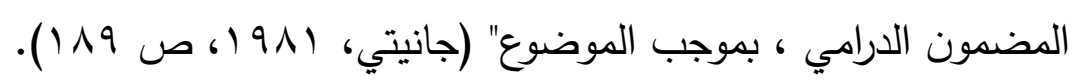

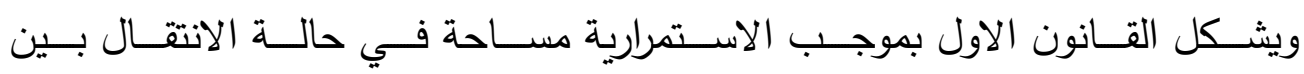

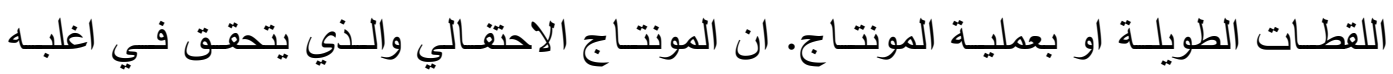

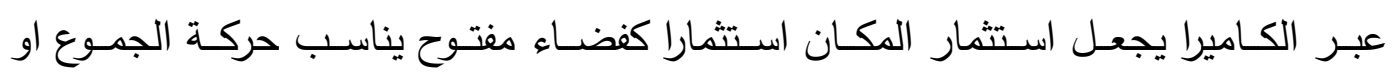

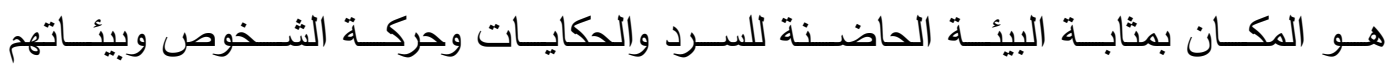

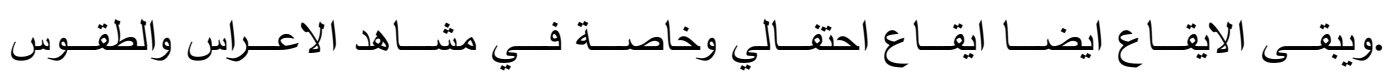

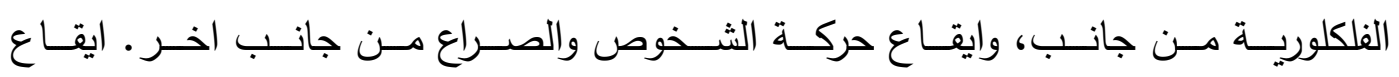

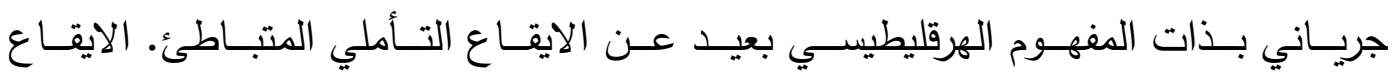

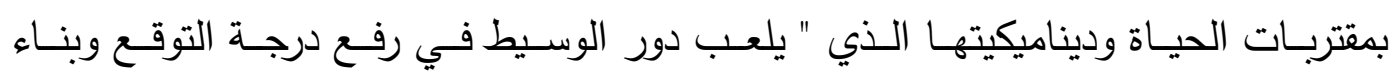

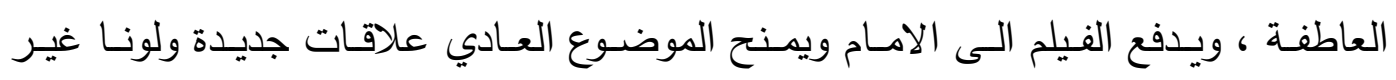

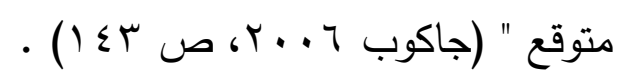

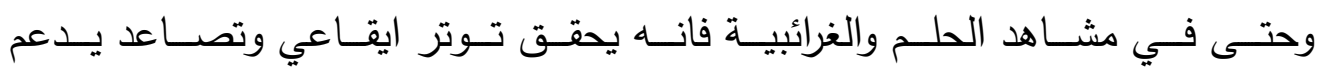

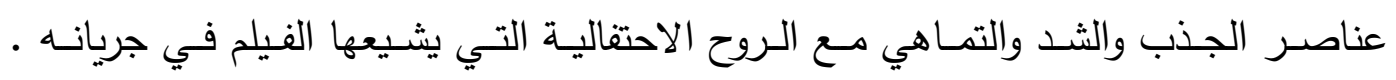

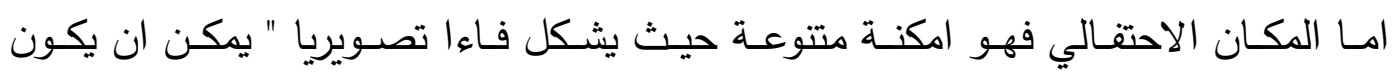

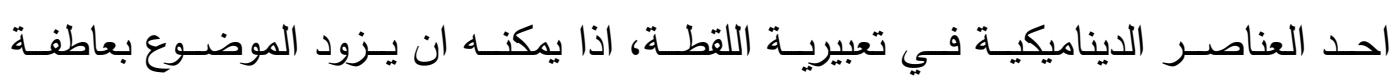

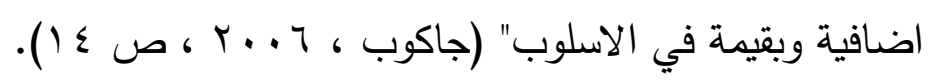

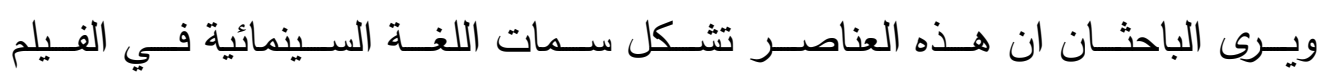


الثيمــات والســرد :تتميـز الثيــات الاحتفاليـة بخصوصـية تقاربهـا مسن الكرنفاليـة اكثر منهـا حكايـة حيـث لا تقـدم الاحسـاس بمتـون متماسـكة بشكل صـارم، لان تقـديم السـرد الصـارم والمتماسـك يقلـل مـن مقتربـات الواقـع الاحتفـالي، الـذي يبنى على شـبه ارتجـال وتحييـد الاحسـاس بـان للمخـرج دور في رسـم مسـار الثيــات، ليوصـل الاحسـاس بـان الامـور تجـري بثـكل غيـر مبـرمج دراميـا. تبنـي المتوقـف: وحبكـات ثانويسة متقاطعـة

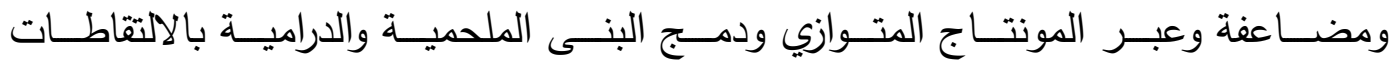
الواقعيـة وعبـر سـرديات غيـر متماسـكة، وهـو يصـور الاحتفاليـات الثـعبية وصـخبها، وخاصــة فـي مشـاهد الزفـاف وكـللك المفارقـات الكوميديـة المصــاحبة التـي تصـل الـى

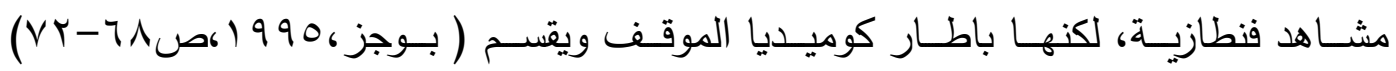

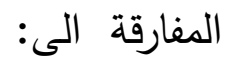
1ـ مفارقـة سـاخرة : تكنيـك ادبـي ودرامسي وسـينمائي ينطـوي على مفارقـة الاضــداد او وصلها

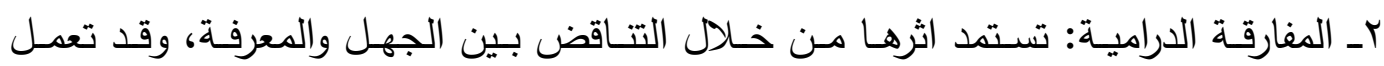
المفارقـة الدراميـة مـن خـلال الحـوار بمـا يحـدث سـخريـة او حركـة الشخصـية او الحـدث والاخيرة تحقق عنصر السخرية او التشويق ولإثراء التأثير العاطفي والفكري.

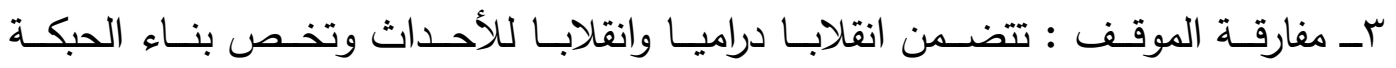
الدرامية وتحقق الثد والحل . الدعل

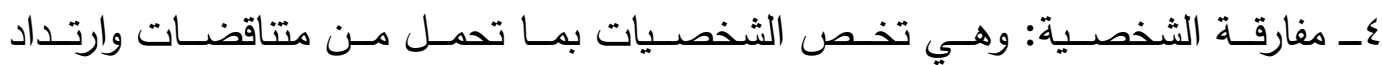
تلك المتتاقضات بما تمر به هذه الشخصيات من مواقف. هـ مفارقـة المنظـر : وهـي تخـص وقـوع حدث في غيـر مكانـهـ كمثـال حدوث ولادة في في

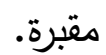
Tـ مفارقـة النغــة او الطـابع العـام : وهـي تقـدم المواقـف العاطفيـة المتتاقضـة وكمثـال التناقض بين حدث واغنية مناقضة للحدث . V ـ المفارقـة الدنيويـة: حيـث يقـدم الحيـاة بصـورة تراجيديـة وكوميديـة معـا وهـي سلسـلة

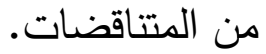
ويـرى الباحثـان ان عناصـر المفارقـة المـذكورة اعـلاه بكـل تنوعاتهـا تشكل عناصـر بنائيـة في الفـيلم الاحتفـالي، لكـن بمسـتويات تخضــع لأسـلوبية المخـرج ورؤيسة الـنص،

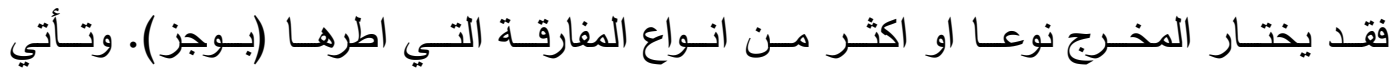
الشخصـيات فـي الفـيلم الاحتفـالي وتتوعاتهـا وصـراعاتها كركيـزة لخلق السـمة الاحتفاليـة وحركتهــا داخـل فضـاء الفـيلم كمـا تشـكل عناصـر جــب حيــث ان لـم نشـفف بـأكثر 
عناصـر الفيلم انسـانية وهـو شخصـياته ،فـان الفرصـة ضـئيلة امامنـا ان نشـفف بـالفيلم

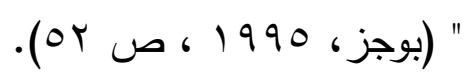

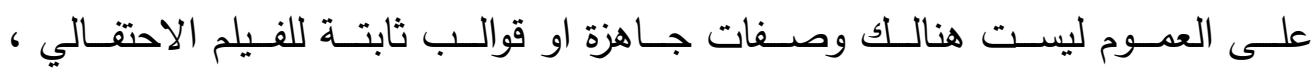

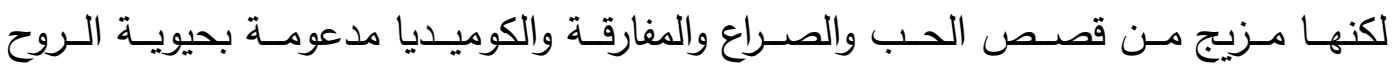

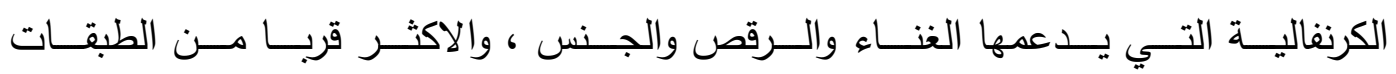
الاجتماعيات المتوسطة .

امـا مسـويات السـرد التي تتاولهـا الكثير مـن المنظرين في علـم السـرد والسـرديات

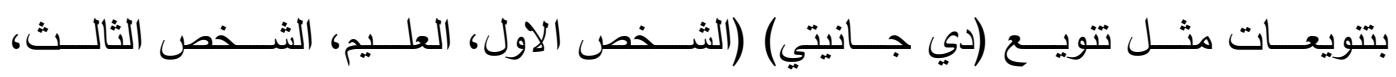

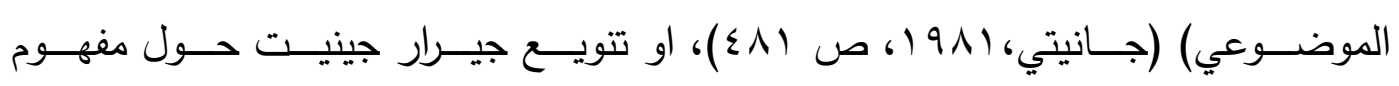

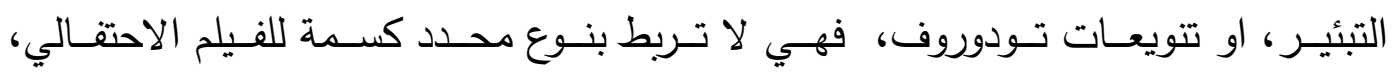

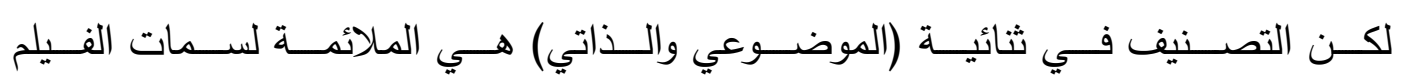

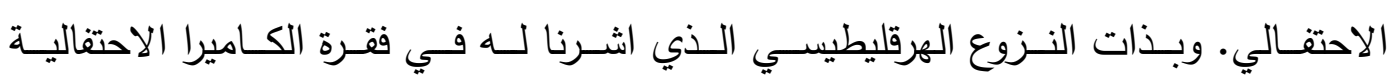

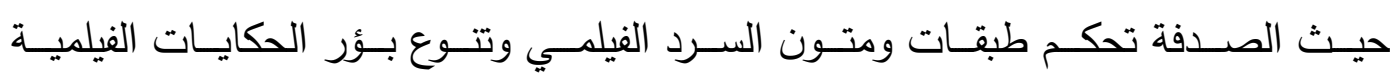

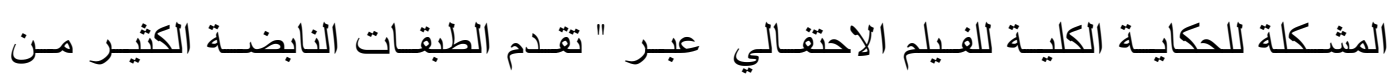

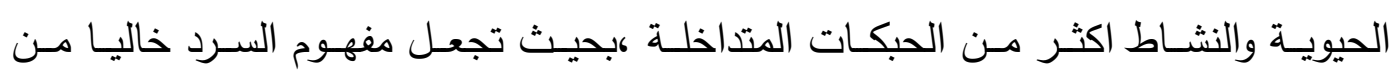

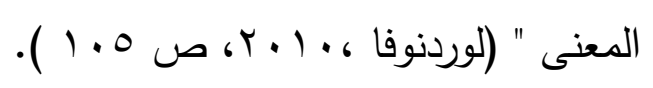

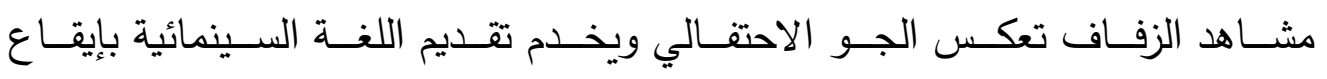

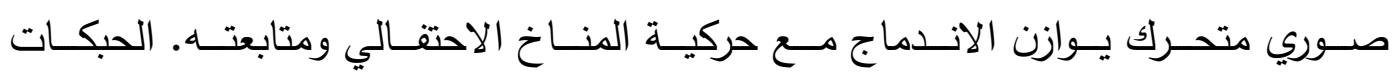

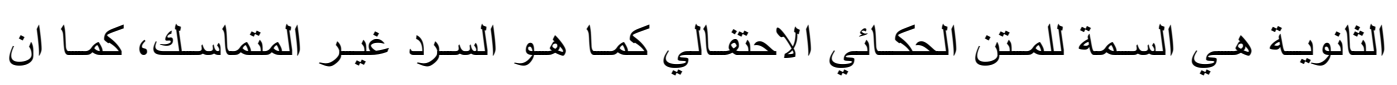

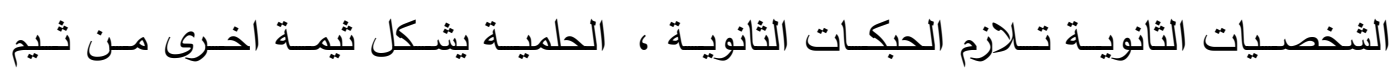

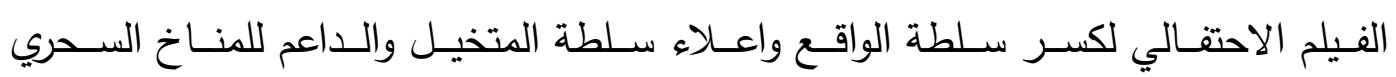

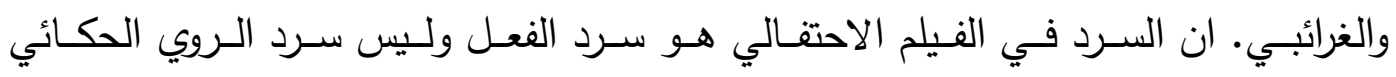

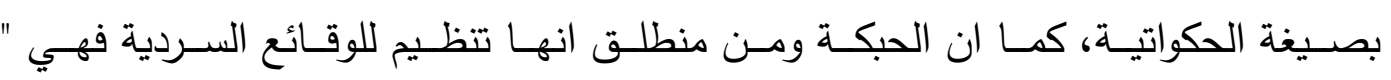

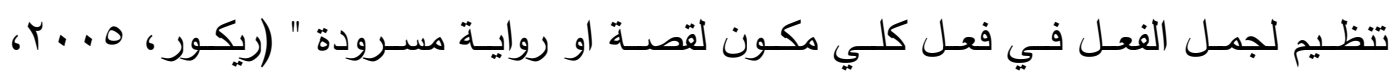

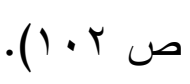

نصــانية الفعـل الاحتفــالي تسـتند الـى التجسـيد حتــى فـي مشــاهد الحلميــة

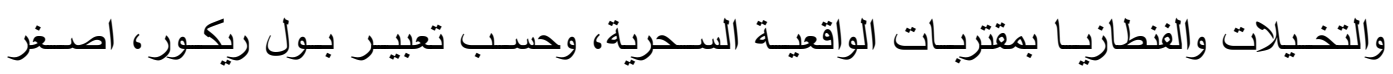

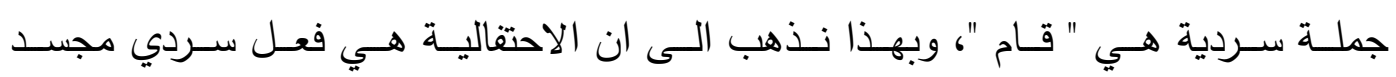

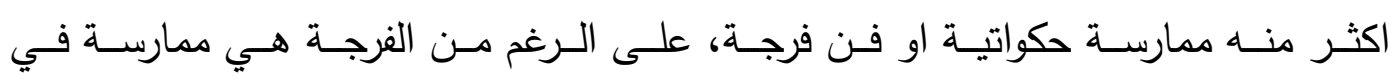




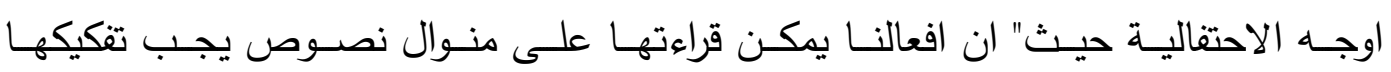

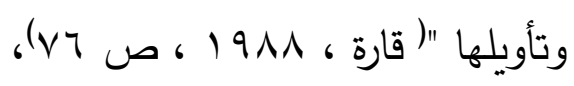

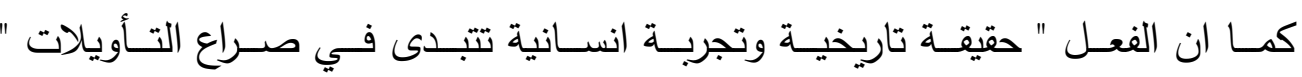

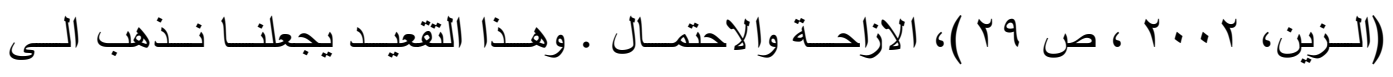

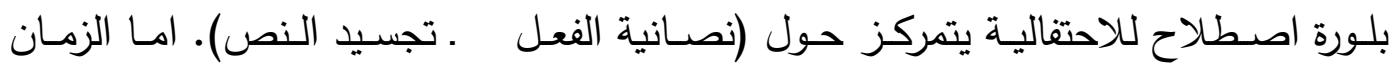

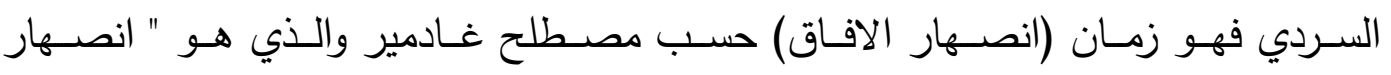

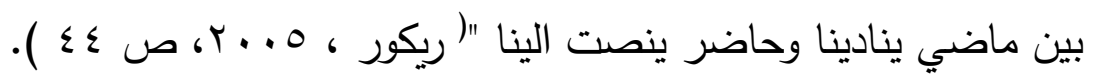

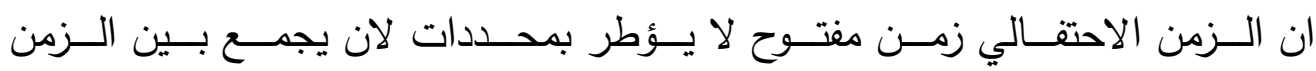

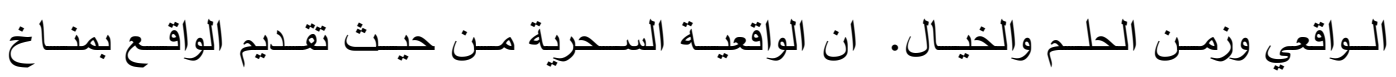

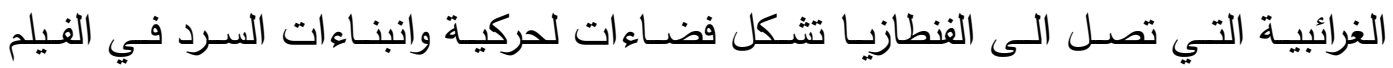

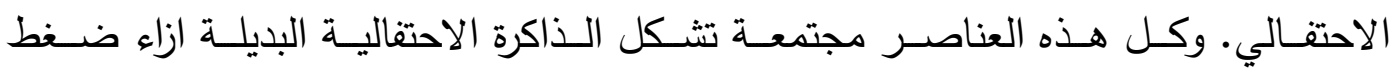

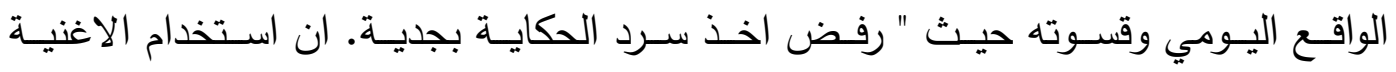

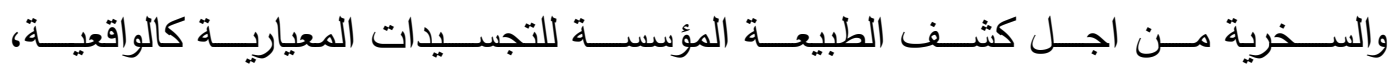

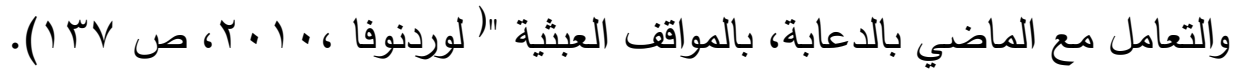

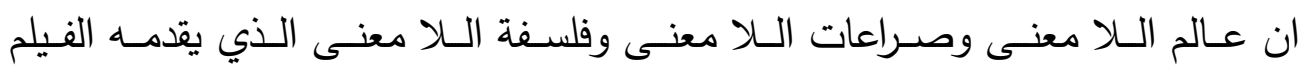

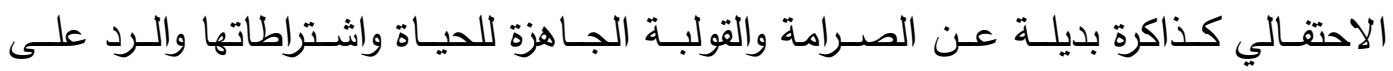

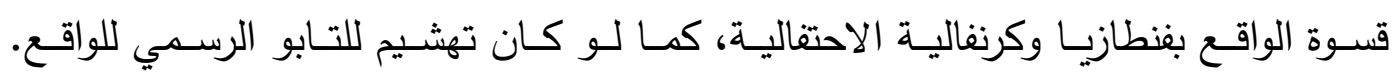

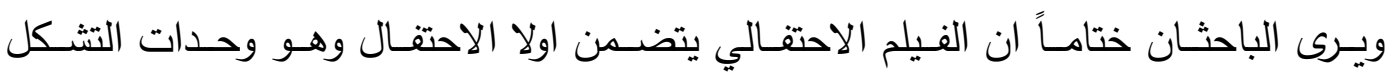

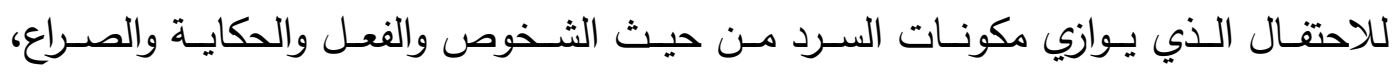

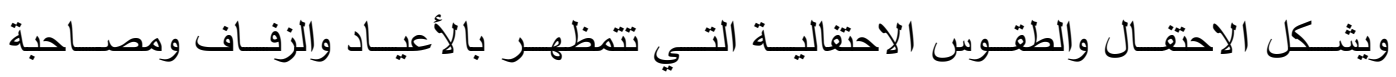

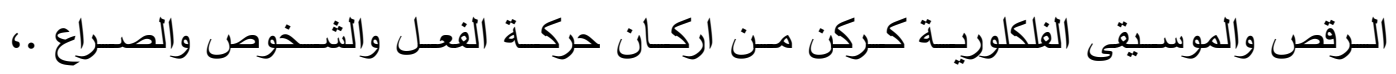

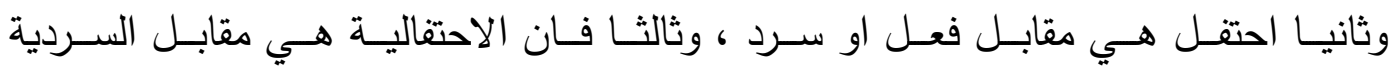

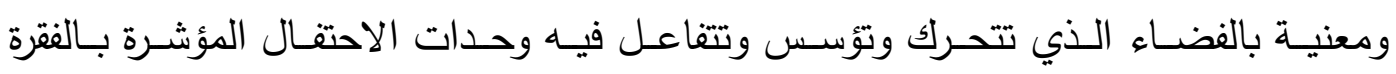

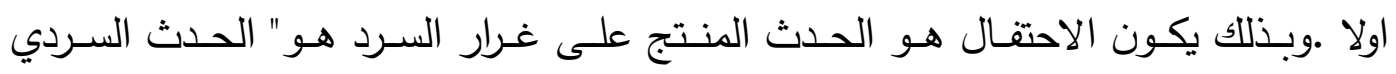

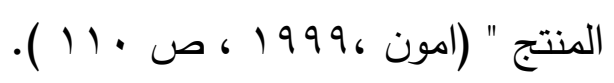
المبحث الثاني: تمثلات الاحتفالية في الفيلم السينمائي ، المون

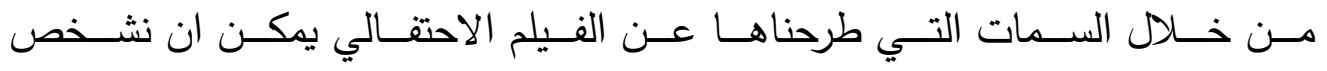

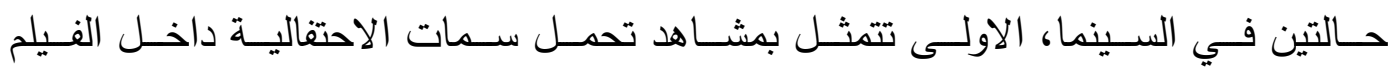

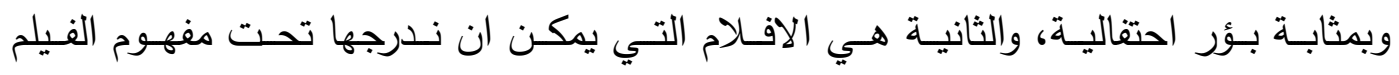

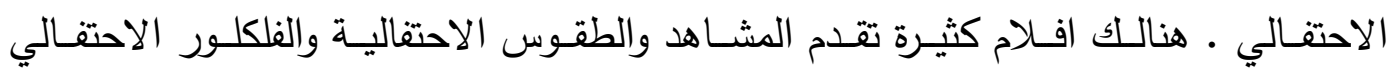




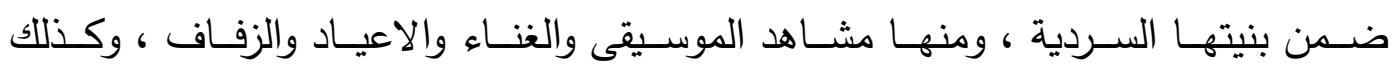

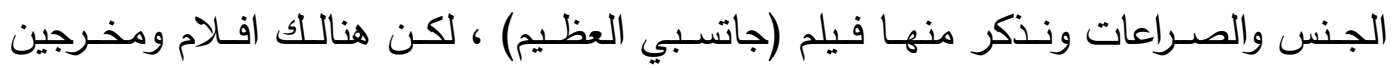

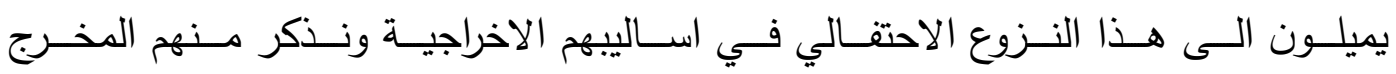

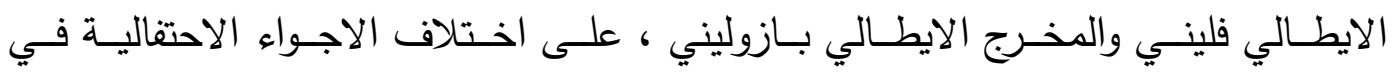

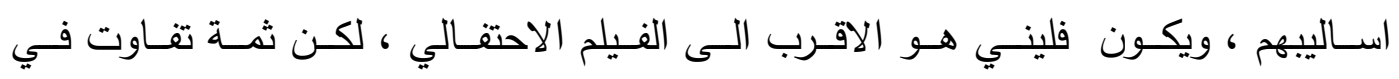

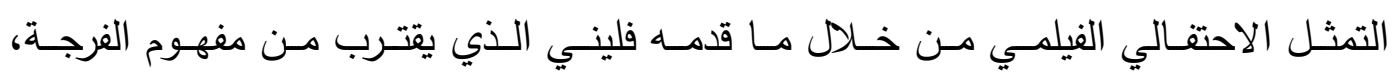

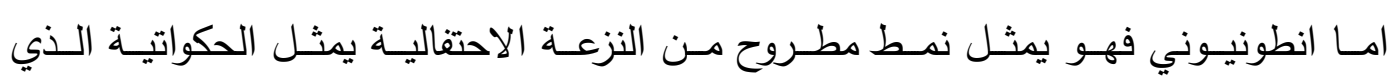

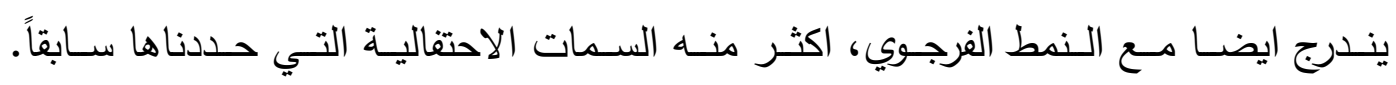

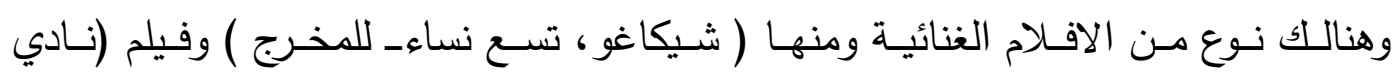

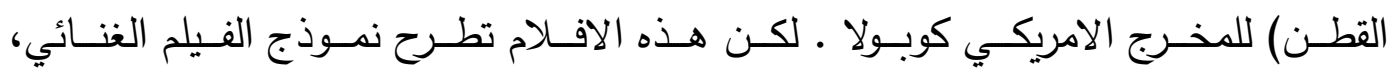

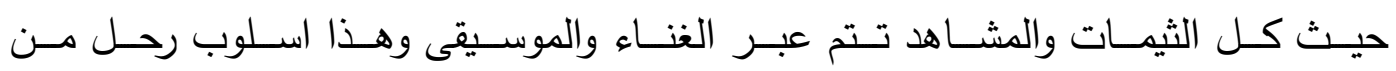

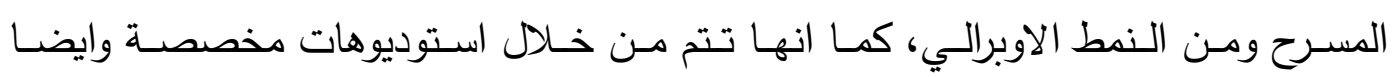

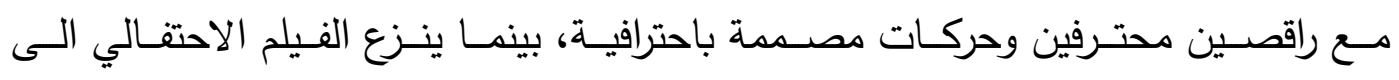

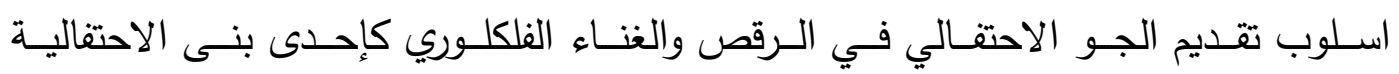

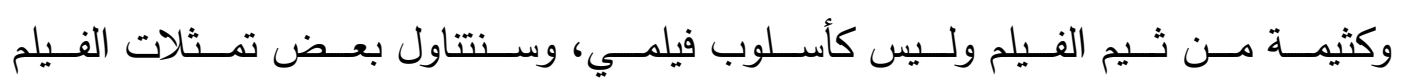
الاحتفالي:

بـازوليني والحكواتيـة :شكلت الف ليلـة وليلة خزين ثري للسينما فقد تم تقديم أول فيلم

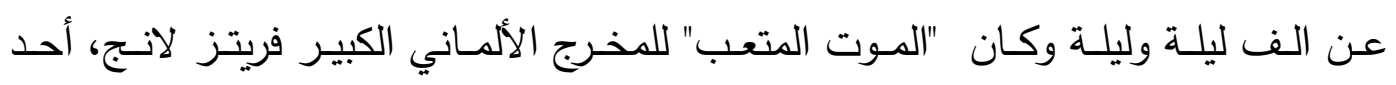

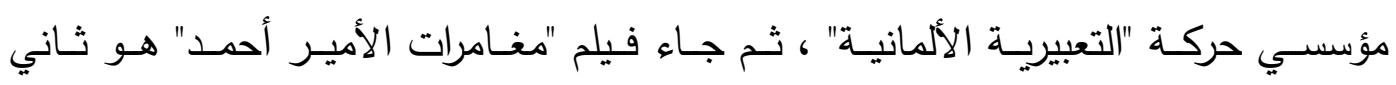

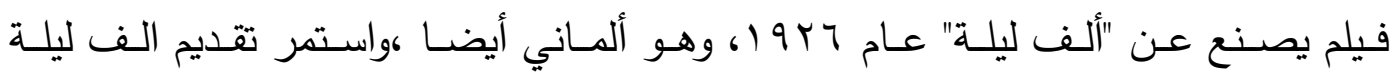
وليلة سينمائيا وبأشكال متعددة.

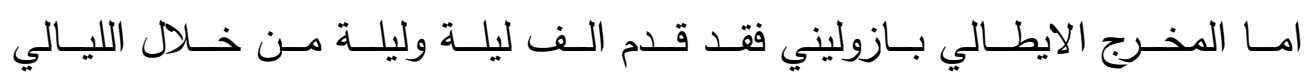

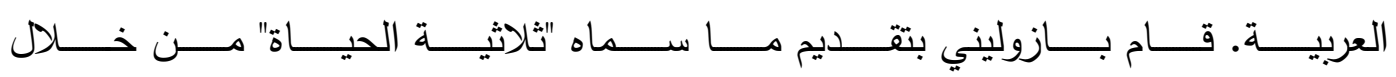

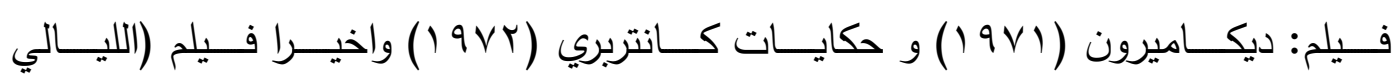

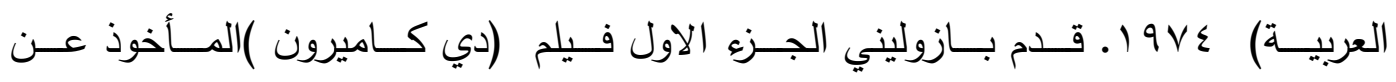

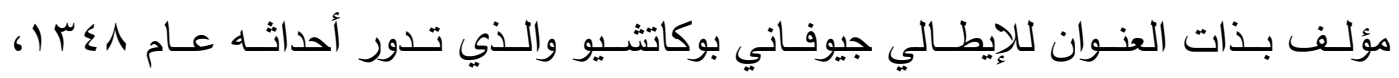

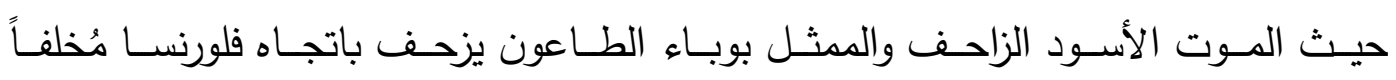

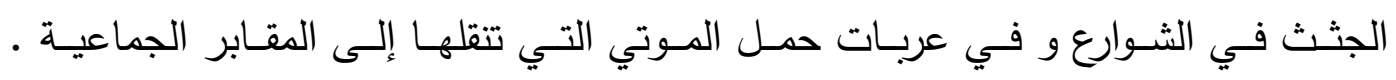

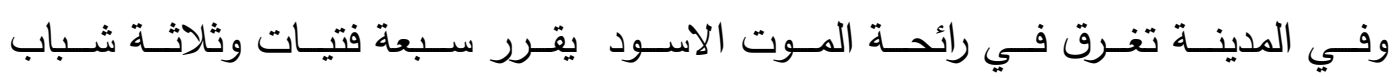

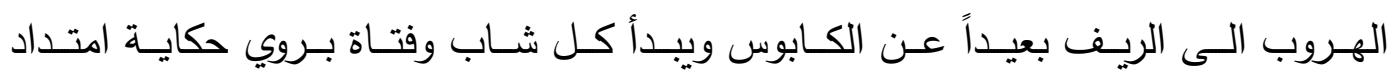


لعشـرة أيـام ـ كـل حـول تـدور حــول ثيمــة الحـب والـم العشــاق وحـزنهم لعـدم الفـوز بــالمحبوب ســواء بــالموت او المــرض او التفــاوت الطبقــي بـين العشــاق ويتخللهــا المواقـف الكوميديـة. قصـص الحـب تقـدم الصــدق والإخـلاص والتضـــية. أن ابطـال تلك القصـص هـم الثـباب العشـرة هـم الـرواة وهـم ابطـال الحكايـا الذين يقومـون بالسـرد وإعـداد الطعـام والسـباحة واللهـو تحــت المطـر ـ انــه اصــرارهم وتثـبثهم بالحيـاة مقابـل المـوت. صــراع بـين الثانتوسـية القادمـة بمحمـول الطـاعون والحيـاة ممثلــة بالحكايـات كـذاكرة وكوجـود .امـا (حكايـات كـانتربري) التـي كتبهــا الإنكليـزي (جيفـري تشوسـر) أواخـر القـرن الرابـع عشـر، تعتبـر واحـداً مـن أهـم الأعمـال في تـاريخ الأدب الإنكليـزي،. وإذا كـان تشوسـر شـرع في العمـل على هـذه النصـوص منـذ حـوالى عـام IN تخطيط تشوسـر للعمـل كـان يفترض أن يتـألف مـن مئسة وعشـرين حكايـة ، لكـن منفــي وصـية تشوسـر لــم يعثـروا بـين أوراقـه بعـد موتـه إلا علـى أربـع وعشـرين حكايـة لـم

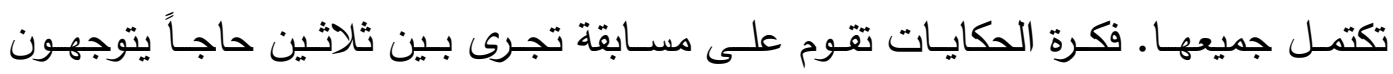

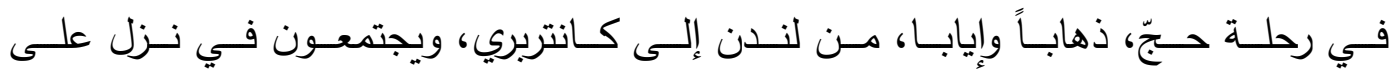
طـريقهم. وفـي النـزل يقتـرح علـيهم صـاحبه أن يـروي كـل مــنهم حكـايتين في طريـق الــذهاب إلـى مكــان الحــج، وحكـايتين أخـرينين فـي طريـق العــودة، وسـتكون مكافـأة صـاحب الحكايـة الأجمـل، أن يتــاول عشـاءه مجانـاً في النـزل عنـد العـودة. هكذا، يبـدأ كـل واحـد مـن الحجيج سـرد روايـة، ولكن أيـام تشوسـر انتهـت مـن دون أن تمكّنـهـ مـن توفير حكايات لكل الحجاج المشاركين. ثـم قـدم بـازوليني فيلمـهـ (الليـالي العربيـة) مـن خـلال مجموعـة قصصـية واحـدة، كانــت منهـا حكايـة فتـى بـريء يـدعى نـور الـدين يقـع فـي غـرام جاريـة تـدعى زمـرد يلتقـي بهـا في سـوق تجـار الرقيـق، تختـاره ليكون سـيدها، اثـاء غيـاب نـور الـدين يـتم اختطـاف زمـرد مـن قبـل البـدو، يسـافر نـور الـدين بحثـا عنهـا. اسـتطاعت زمـرد الهـرب والتتكـر بـزي الرجـال، رحلـت إلى مملكـة بعيدة جـدا حيـث هنـاك تصـبح الملـك وتتتهي

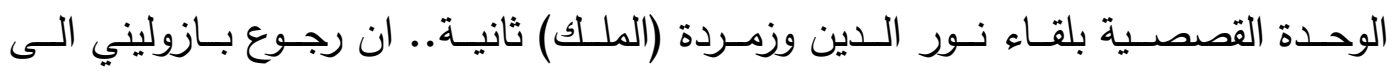
المـوروث الحكـائي ليــرر مـن خلالـه تهــيم التـابو السياسـي والـديني والجنسـي ، وهـذا هـو الهـدف الفكـري لهـذه الثلاثيـة التي اتـت بصـيغة السـرد الحكـواتي مـن قبـل المخـرج وعبر مزج بين السردية والشعرية في فضاء الفيلم.

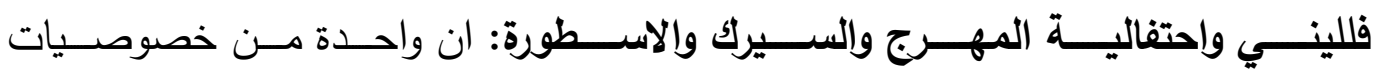
الاسـلوب الابــاعي لفلينـي انــه رسـام للصــورة السـينمائية، والتـي هـي البنيـة الثـعرية

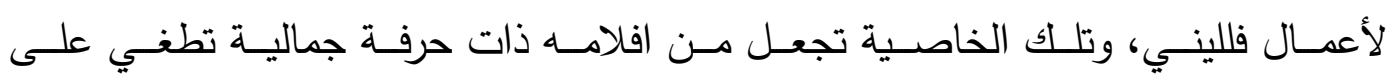


الاسـلوب الاحتفـالي الـذي مـن سـماته ان لايغـرق فـي تحويـل الفـيلم الـى منظومــة علاميـة تشـفيرية اكثر منهـا سـرد احتفـالي. الصـورة ذا قيمـة تشـكيلية عاليـة يضــخ فيهـا الـى جانـب البـــاء الجمـالي لتحقيـق الدهشـة البصـرية فهنالــك الـزخم الرمـزي والتشـفير •

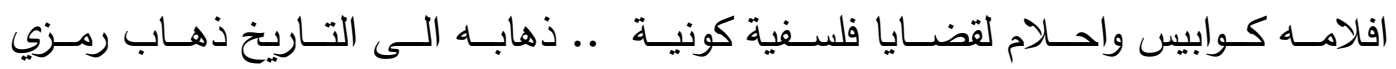

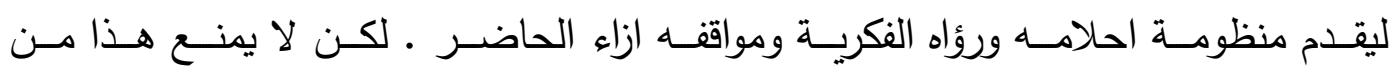

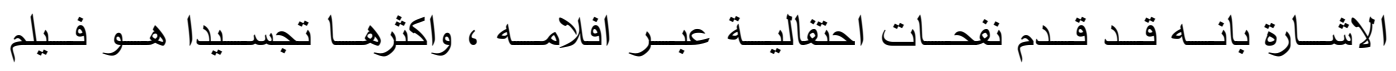

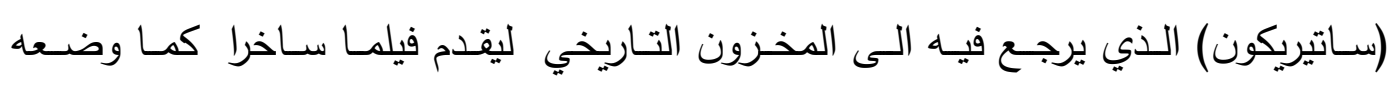

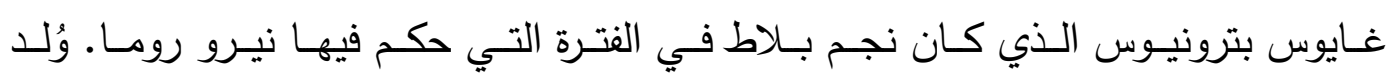

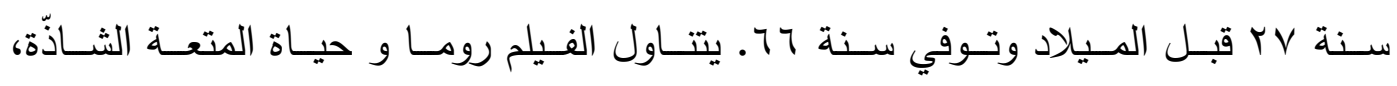
أحـداث حـب مثلـي بـين أسـياد وعبيـد تشـهد حـالات انتقـام وحـالات أخـرى مسن الغيـرة والحسد والقتل.

امـا فيلم (كازانوفـا)، فهـو فـيلم آخـر ينـبش الماضـي التـاريخي ايضــا، ليقـدم فيلم سـيرة اكثر منـه فيلمـا احتفاليـا على الـرغم مـن وجـود سـمات احتفاليـة. انـه يقـدم برؤيـة فلسـية تحلـل الحاضـر مـن خـلال عـرض تحلـل الماضـي.. تقـديم حكايـات عـن التحلـل الانســاني. ومـرة اخـرى يقـدم الصــورة بريشــة مخـرج سـينمائي .. الاضــاءة مصـــوعة بحرفيـة جماليـة تقلـل مـن زخـم الـروح الاحتفاليـة الكرنفاليـة الاقـرب للفلكلوريـة الثـعبية. كل صـوري مـتقن بحرفيـة يقـدم الثـعرية على حسـاب الـروح الاحتفاليـة التـي تميـل الى الى

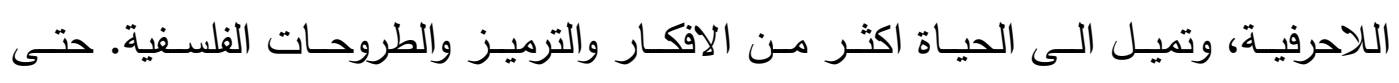
الحلميـة هـي حلميـة شخصـيات الحاضـر داخـل الفيلم الاحتفـالي. ان كـان ثــة احتفاليـة يقدمها فللينـي فتــدرج ضـمن مفهوم (الفرجـة) الـذي هـو احـدى السـمات الملحقـة بـالفيلم الاحتفـالي، حتى مـع تقديمـة السـيرك والمهـرج، فـان السـيرك ينـدرج ايضــا ضـمن مفهـوم الفرجة الاجة

سيوســلوجيا وســياكلوجيا الاحتفــال الفيلمــي: انطلاقــا مـن مقولــة ان الفـيلم خيـالي

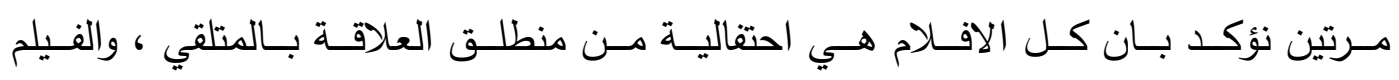

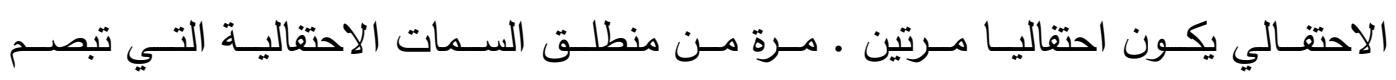

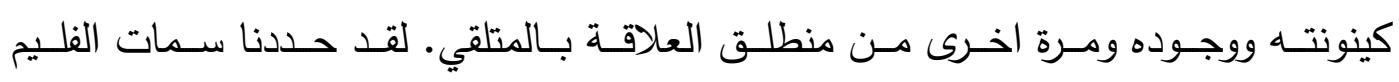
الاحتفـالي ، لنتتقل الى سيوسـلوجيا وسـايكلوجيا الاحتفـال الفيلمي الذي يجعـل مـن هـذهـ العلاقـة هـي علاقـة احتفاليـة، حيـث يـتم الاهتمـام بالمشـاهد كجـزه مـن مجتمـع الفـيلم او

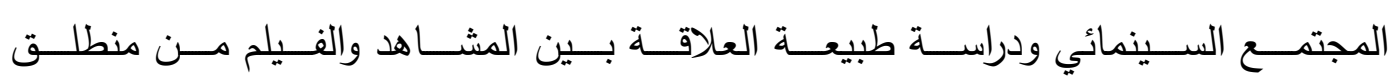

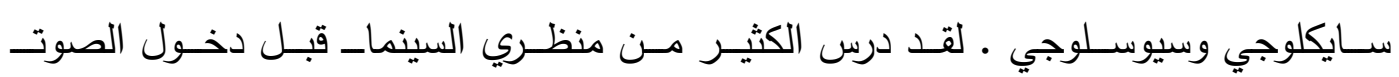


هـــه العلاقــة ومنهم(هوغـو مونسـتربيرج) و (رودولــف ارنهـايم). وقـــم (مونسـتربيرج)

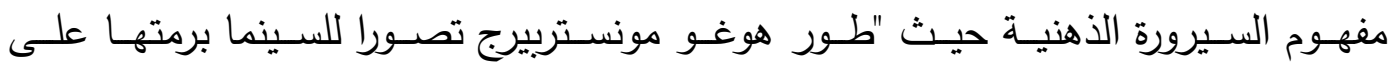

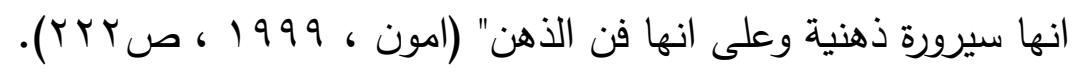

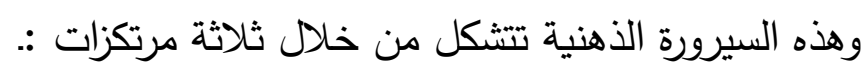

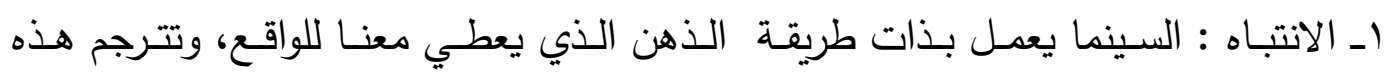
الخاصية من خلال حجوم اللقطات وخاصة اللقطة الكبيرة.

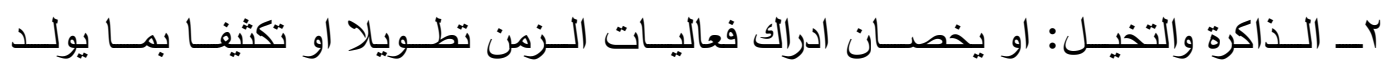
· الايقاع

ومسن خـلال هـــه المرتكـزات يثـير (مونسـتربيرج) الـى محاكـاة السـينما لآليـات

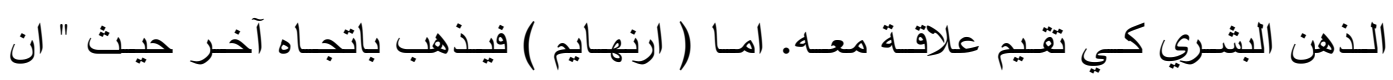

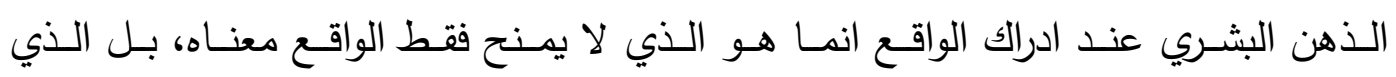

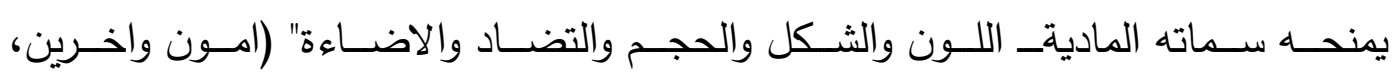

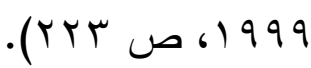

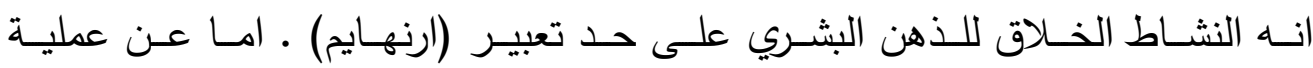

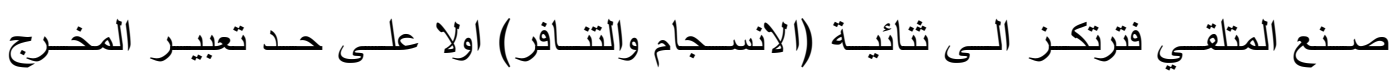

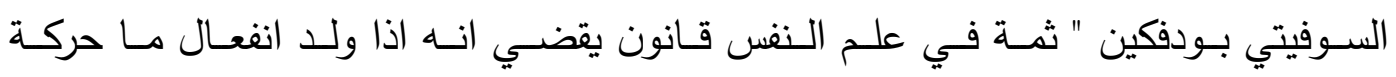

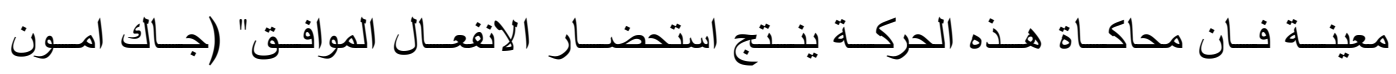

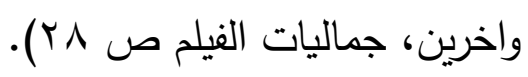

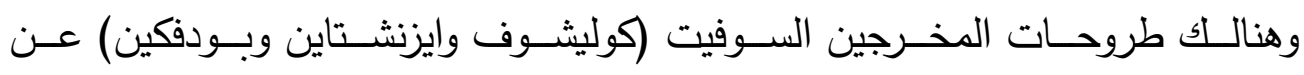

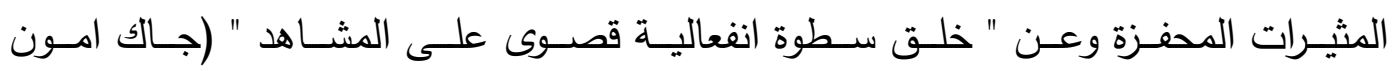

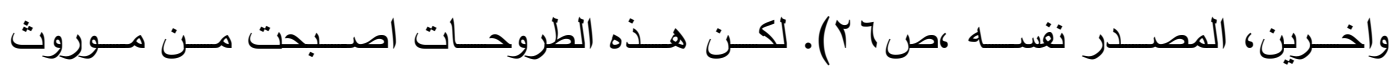

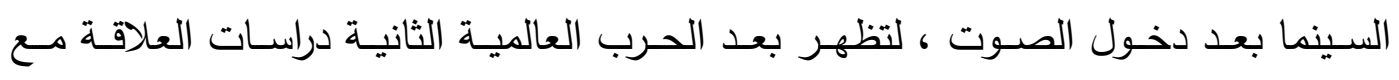

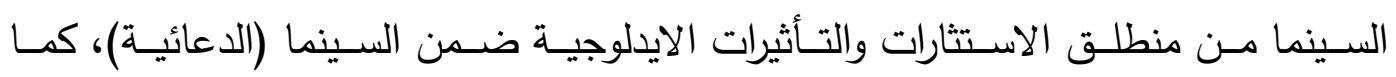

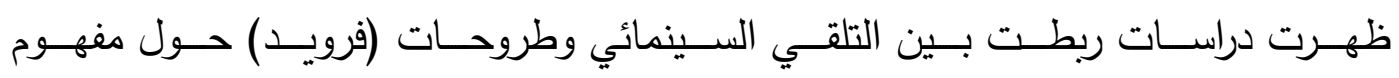

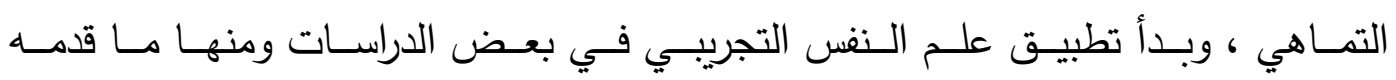

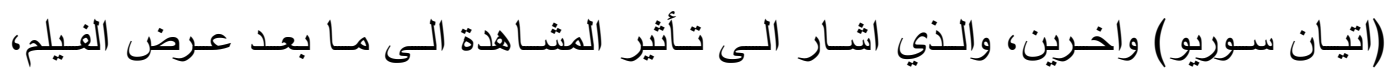

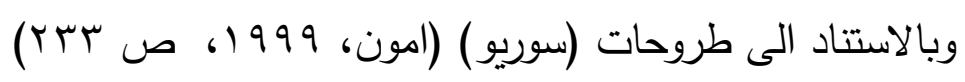

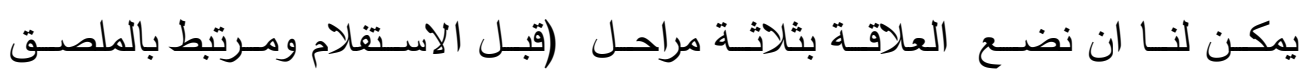

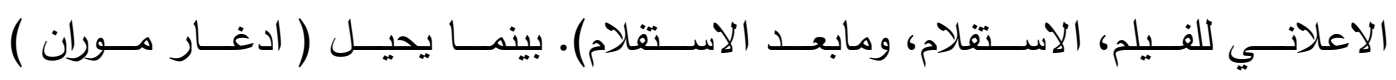

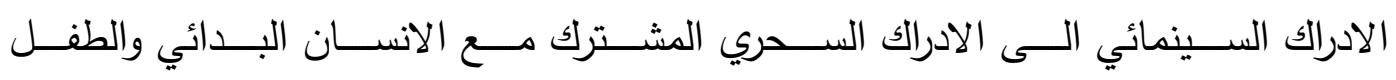




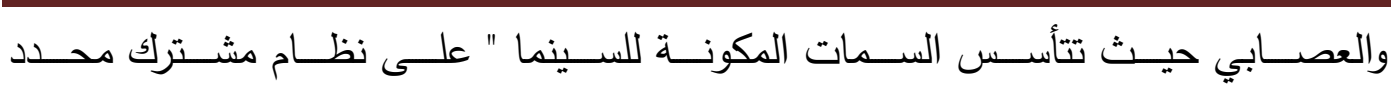

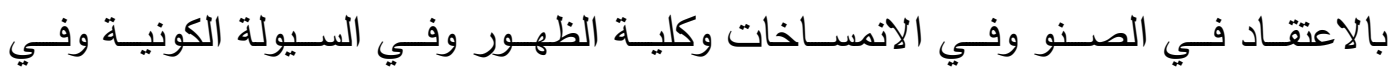

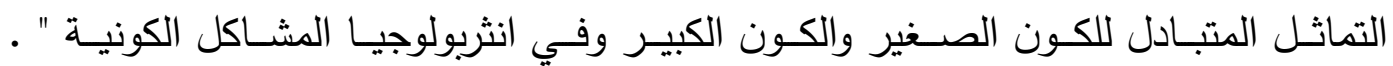

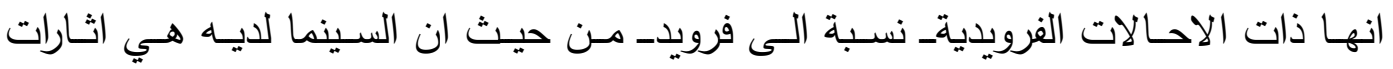

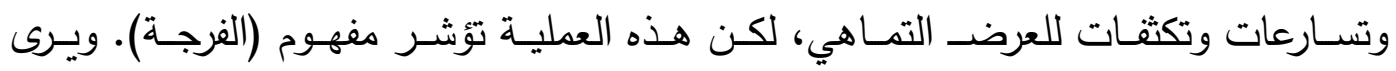

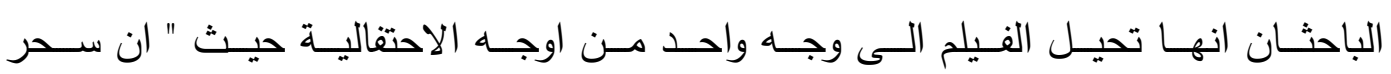

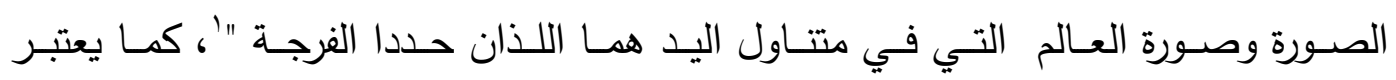
الفيلم فـي بعـض الطروحـات كفعـل تعويضـي عـن نكـوص وتعـويض عـن الخسـارات

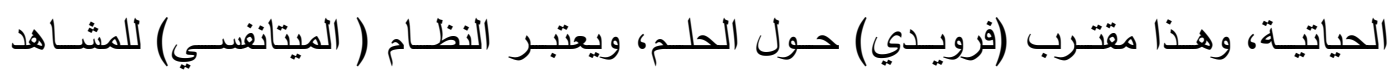

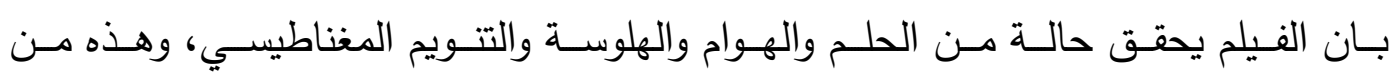

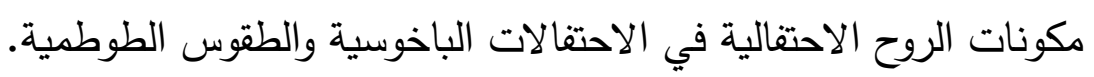

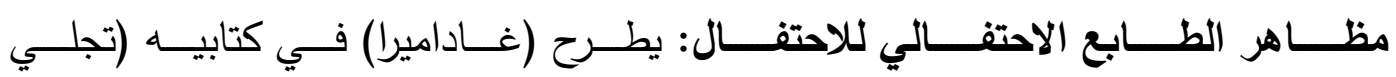

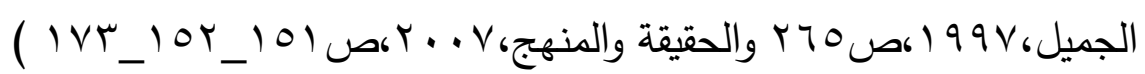

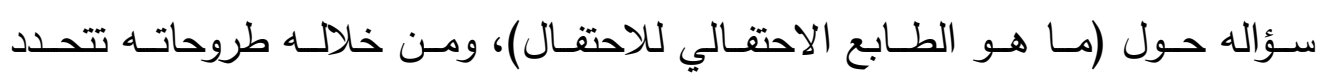

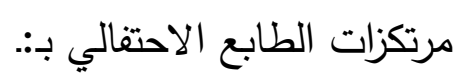

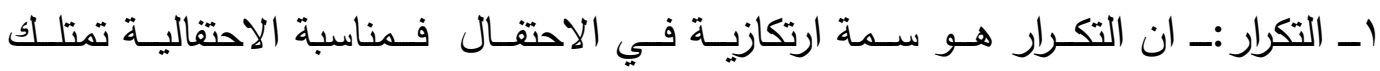

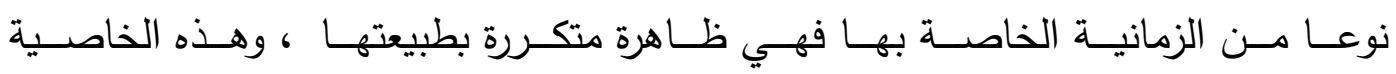

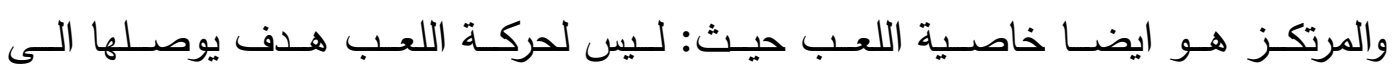

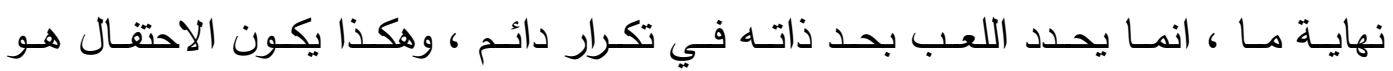

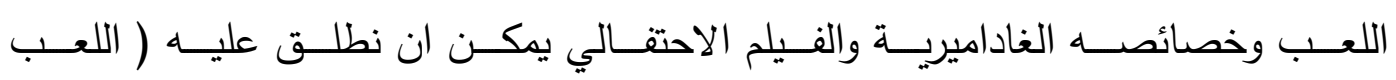
(الاحتفالي).

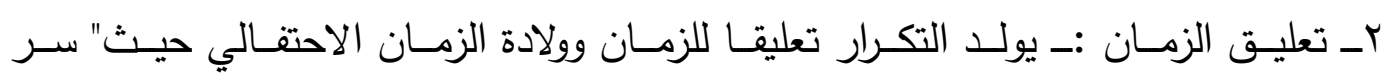
الاحتفال المهرجاني في هذا التعليق للزمان.

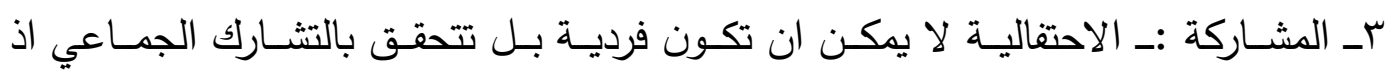

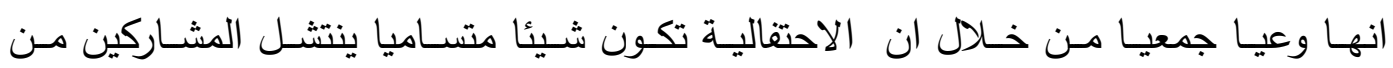
وجودهم اليومي ويسمو بهم الى نوع من التشارك الكلي.

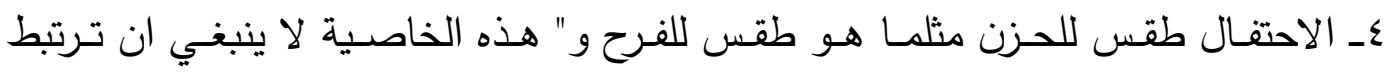

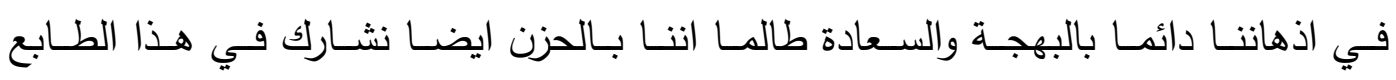

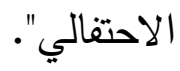




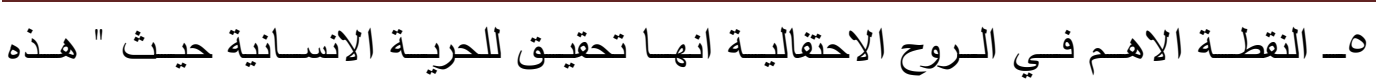

الاشكال من اللعب هي اشكال حريتنا " .

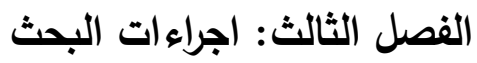

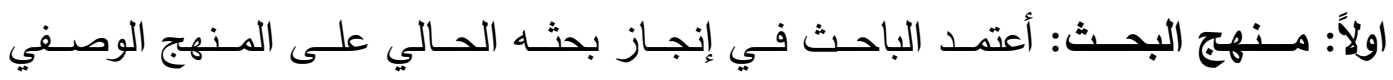

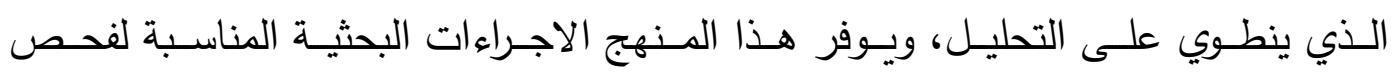
العينات والوصول الى النتائج المتوخاة.

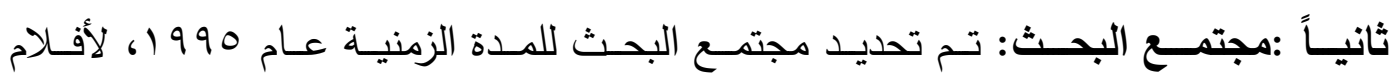

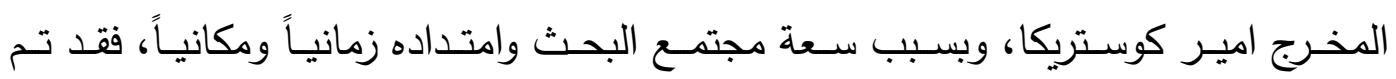
اختيار عينات قصدية للبحث، وللمسوغات سيتم ذكرها في عينة البحث.

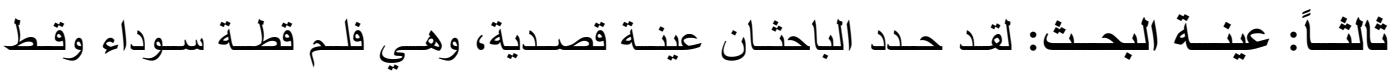

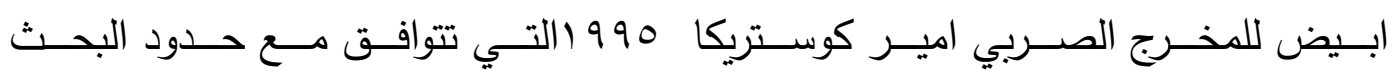

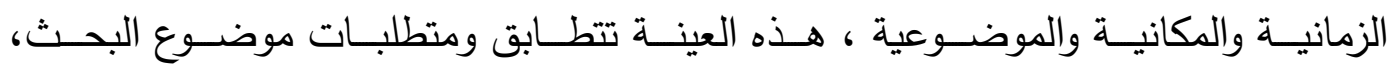

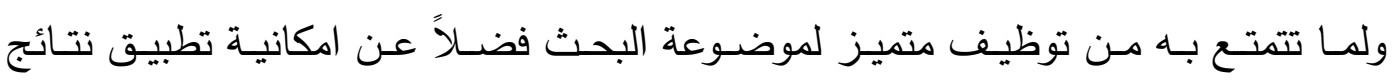

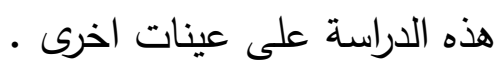
رابعـاً: اداة البحـث: سـيعتمد الباحثـان علـى مــا ورد مـن مؤشــات فـي الاطــار النظـري

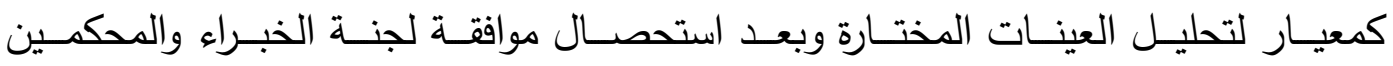
عليها.

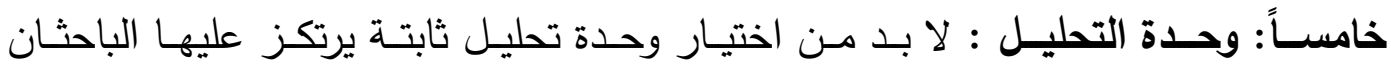

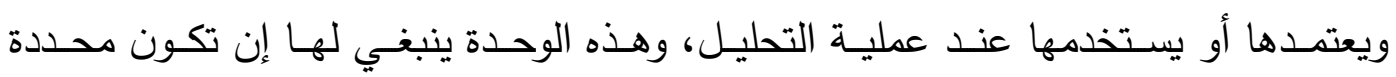

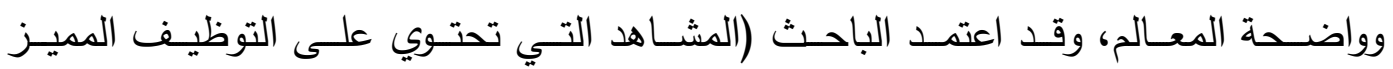
لموضوع البحث ) كوحدة تحليل يستخدما في عملية تحليل عينات البحث .

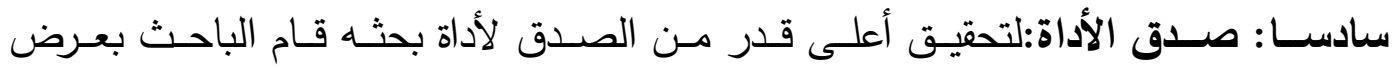

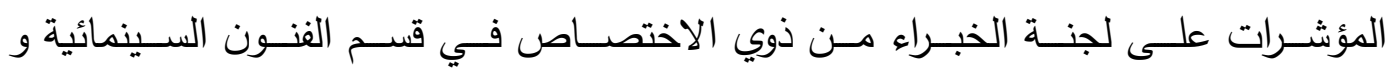

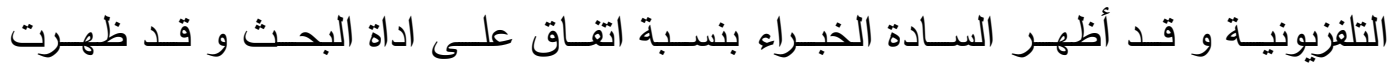

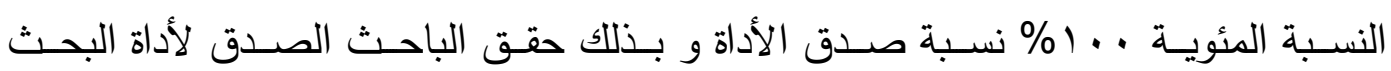

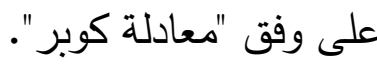
الفصل الرابع تحليل العينة

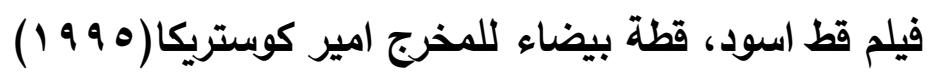

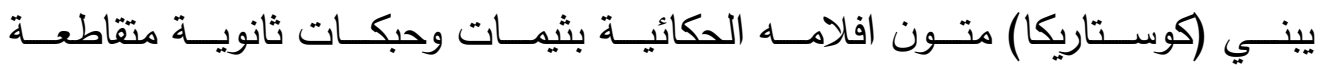

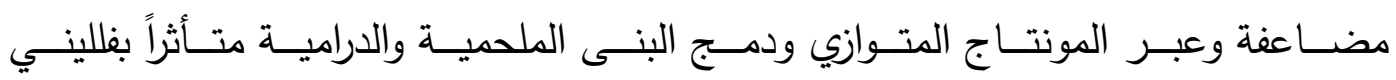


وعبر سـرديات غيـر متماسـكة وهـو يصـور الاحتفاليـات الثـعبية وصـخبها وخاصـة في مشـاهد الزفـاف والمفارقـات الكوميديـة المصــاحبة التـي تصـل الـى مشــاهد فنطازيــة.

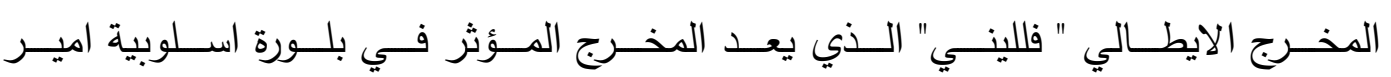
كوستريكا ذات السمات الاحتفالية

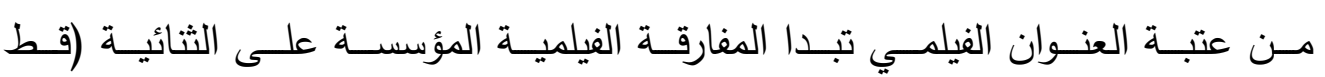

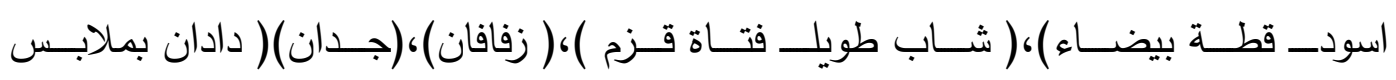

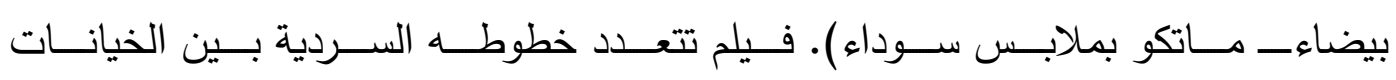
والمـؤامرات ضــمن خمسـة حبكـات رئيسـية وعديـد الثيمـات المضــاعفة التـي لا تسـتـد الا

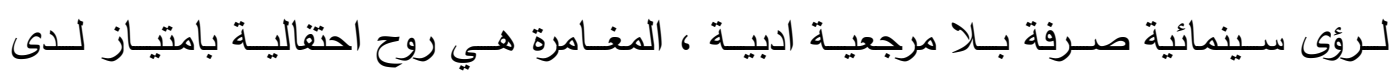
هـذا المخـرج ، الطـيش والصــراع والخـداع والـرقص وحفلـة الزفـاف حيـث " يظهـر الجميـع في الفـيلم مـأخوذا بـنفس الدرجـة مـن الحمـاس والنشـاط والرغبـة بالحيـاة (....) ويعـيش كل الابطـال في الفيلم في العـالم الذاتي في متعـة احتفاليـة " الحبكـات الرئيسية للفيلم التي تقود خطوطها شخصيات الفيلم: 1ـ حبكـة البحث عـن وهـــ الاثراء: مـاتكو الغجري المقيم في كوخ على نهـر الـدانوب

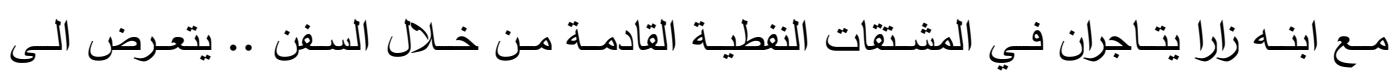
الخديعـة مسن قبـل المهربين الـروس حيـث يبيعونـهـ المـاء على انـه (كـاز) يسـتدين المـال مـن اجـل شـراء عربـات القطــار المحملـة بالكـاز مــع الغجـري القـادم بمظــاهر الثـراء

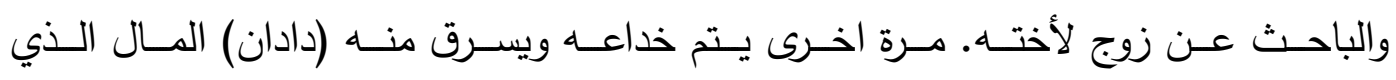
استدانه ويجبره على تزويج ابنه زازا من اخته القزم ( افروديتا ).

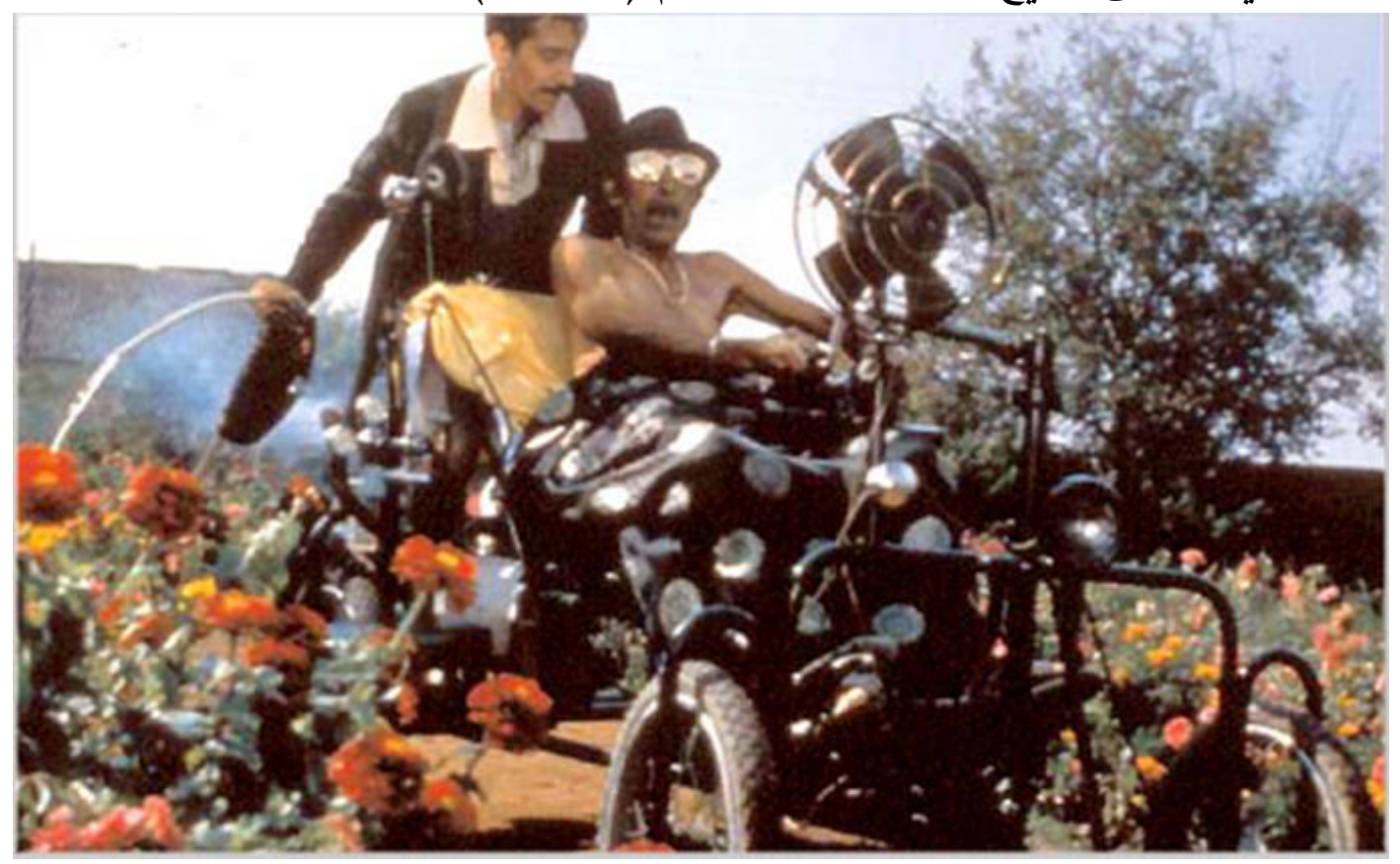




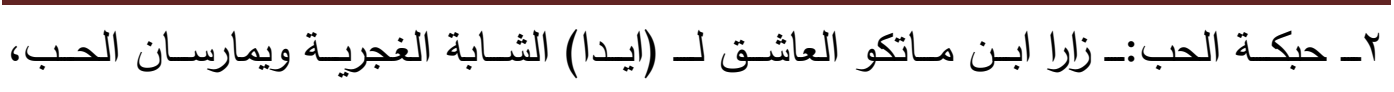
لكنـه مجبر على الـزواج مسن اخـت الغجـري القـادم. يقـاوم زارا هـذا المشـروع للـزواج مـن

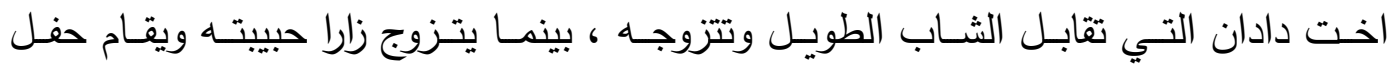

$$
\text { زفاف للزوجين معا • }
$$

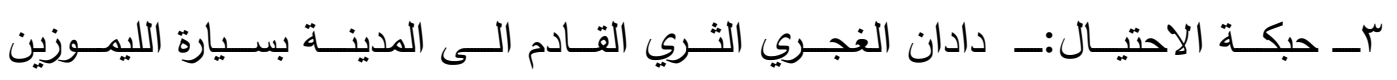

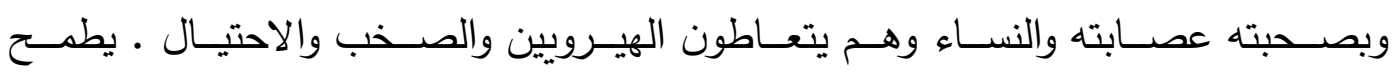

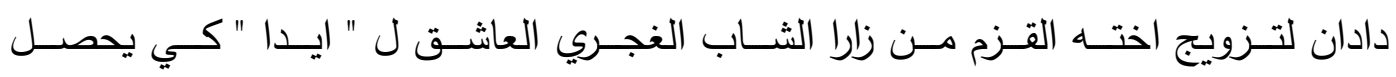
على ورث اباه المتوفي المشروط بتزويج اخته القزم • عــ حبكـة جــ زارا :- يقـود زارا فرقـة موسـيقية لآلات الـنفخ ويـذهب الـى المستشفى حيـث

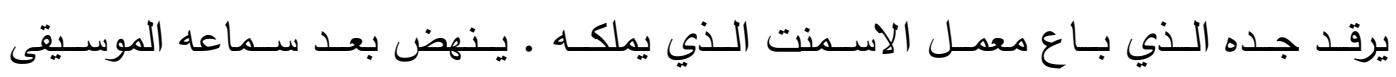
ويخرج في مظهر احتفالي ليتابع الحكايات الاحتفالية .

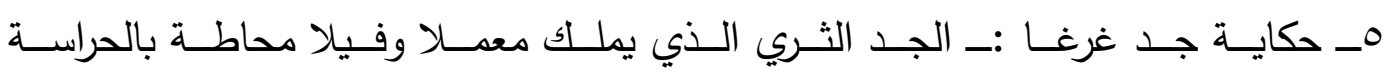
وكـاميرات المراقبـة ويجلس على عربـة متحركـة ـ لديـه ابـن طويـل ( غرغـا) يحثـه على

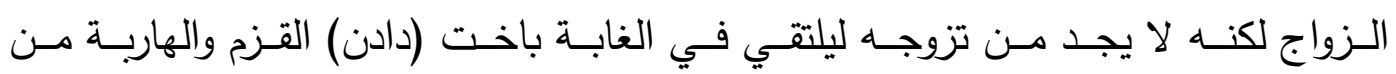
زواجها ب(زارا) ليقع في حبها وتبادله الحب ويقرران الزواج •

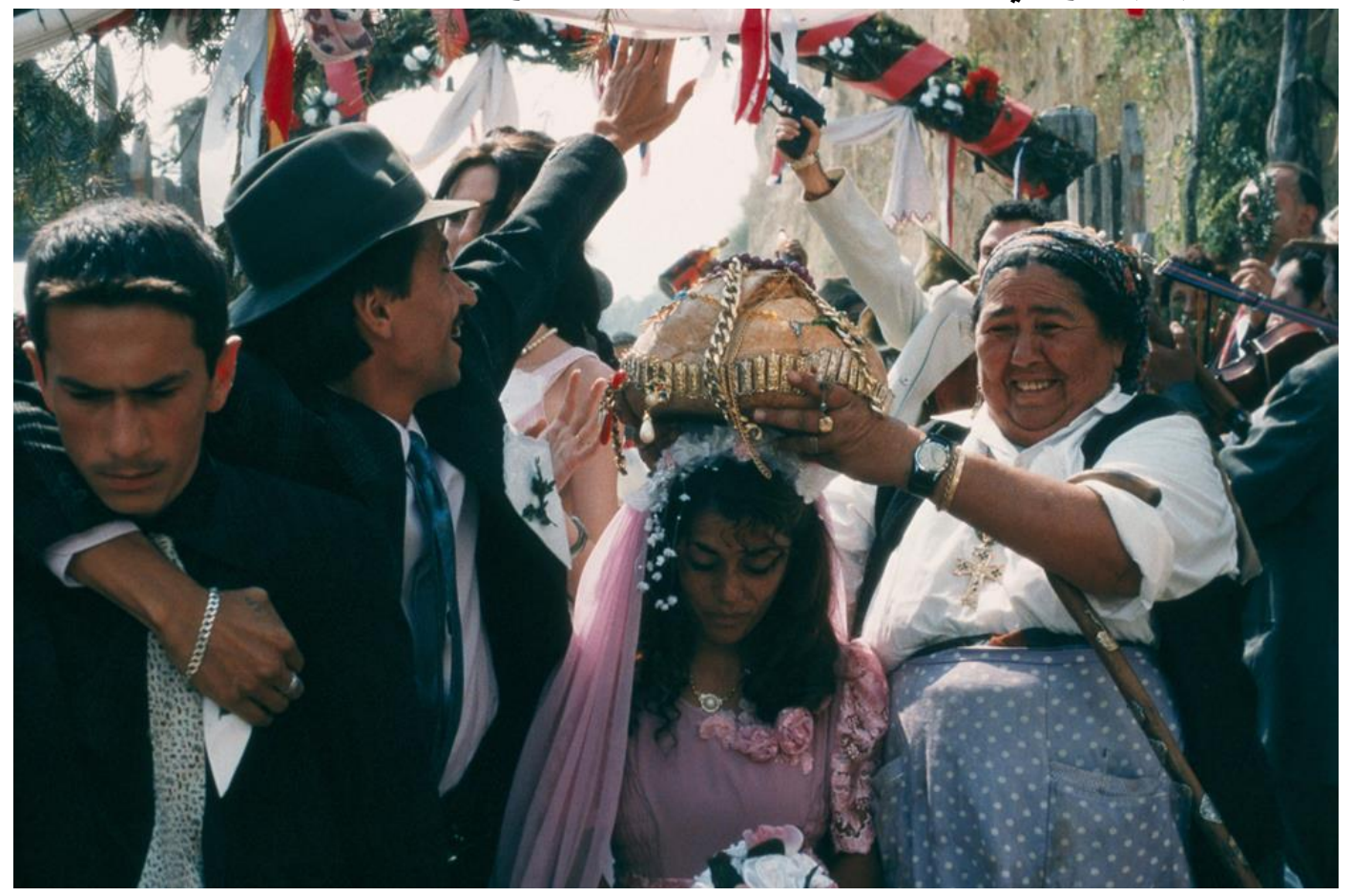

وضـــن هـذه الحبكـات يـدور الاحتفــال الفيلمـي ويتضـــن الكثيـر مـن الحبكـات

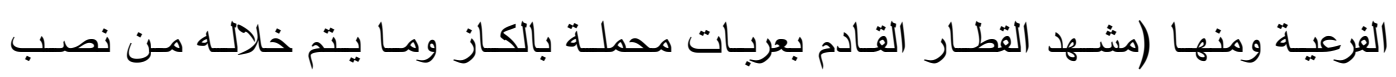
واحتيـال على مـاتكو الحـالم بـالثراء مـن قبـل الغجـري دادان القـادم بعصــابته)، ( مشـهد المطربـة ضــن البـار الـذي تشـرف عليـه الغجريـة ام (ايـدا) التي يعشـقها الشـاب زارا)، 
مشـهـ هـروب القـزم ( افروديتـا) في الغابـة ولقائهـا بالطويـلـ ( غرغــا ) وزواجهــا)..

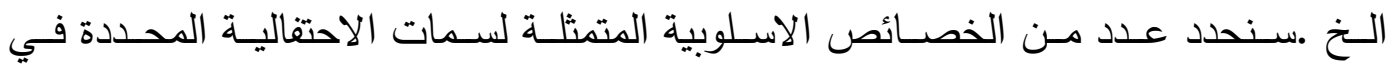
مؤشرات الاطار النظري ومطابقتها لدى "كوستاريتسا " في هذا الفيلم .

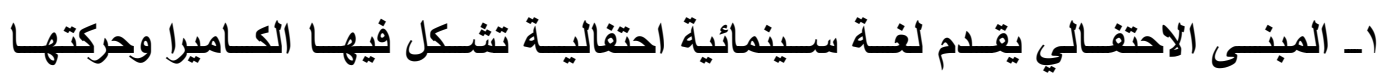

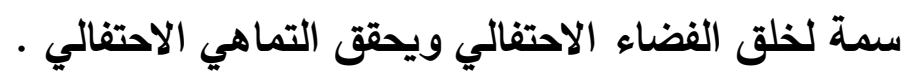

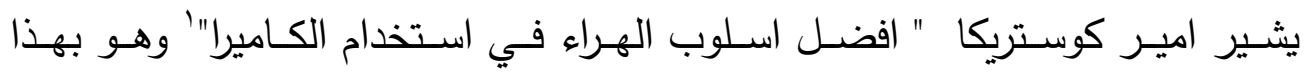

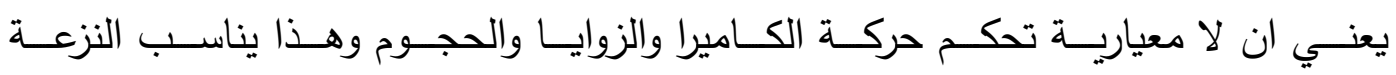

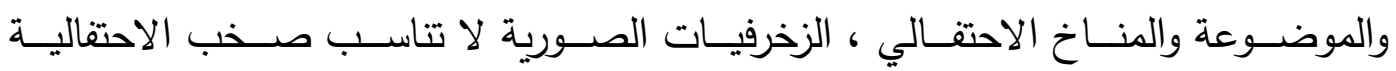

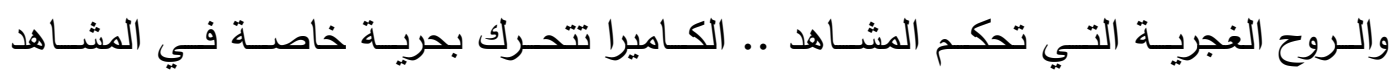

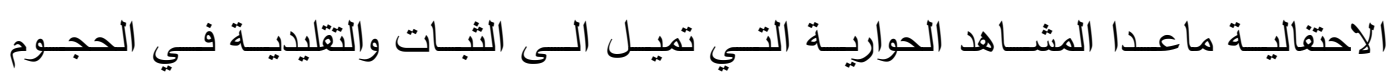

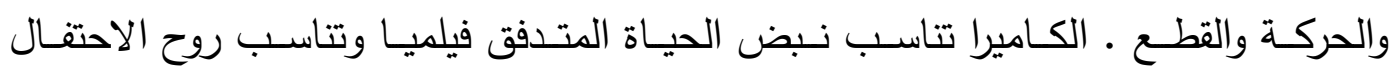

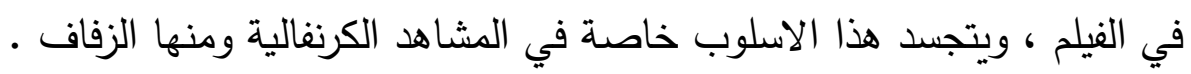

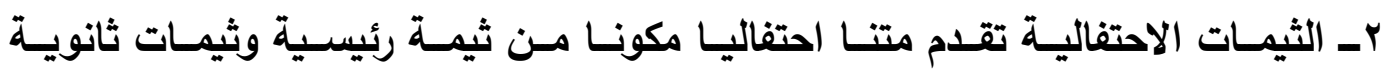

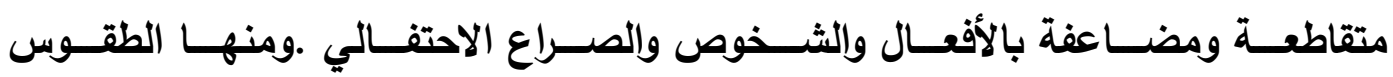
الاحتفالية الفلكلورية

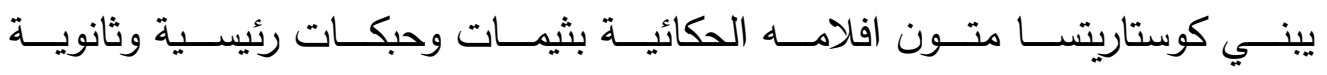

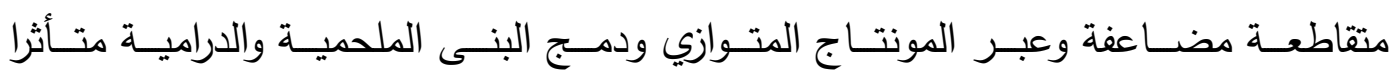

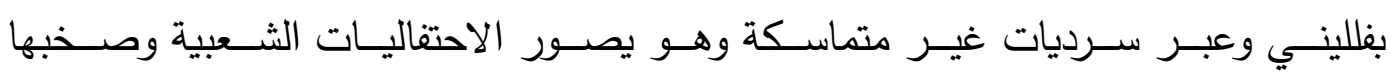

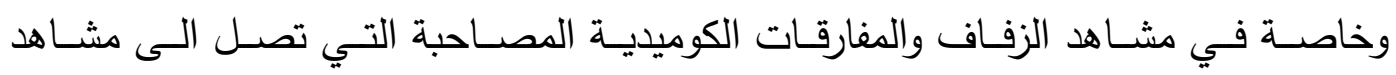

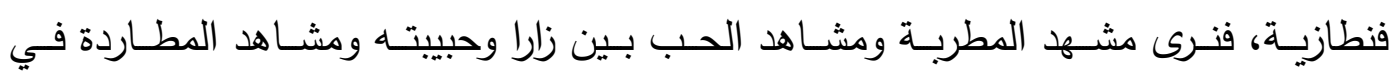

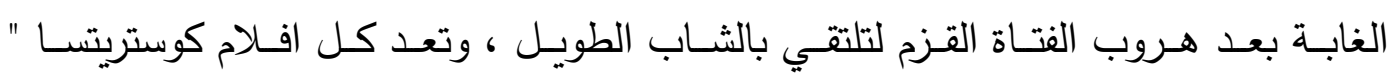

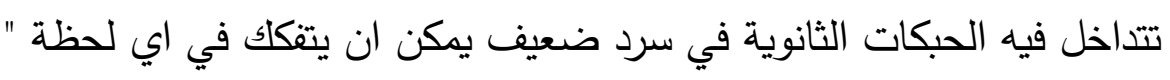

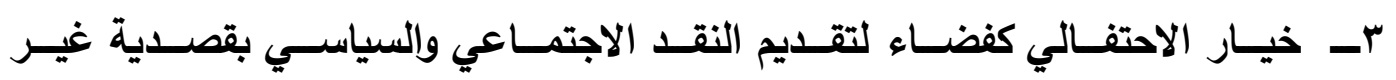

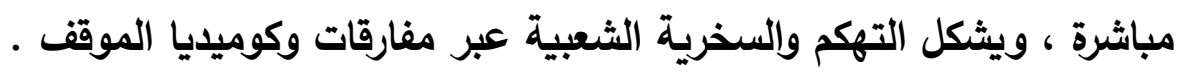

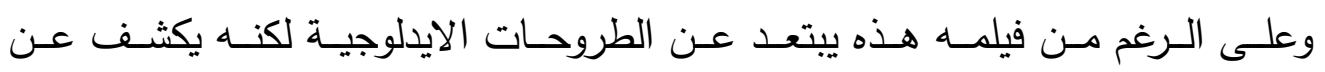

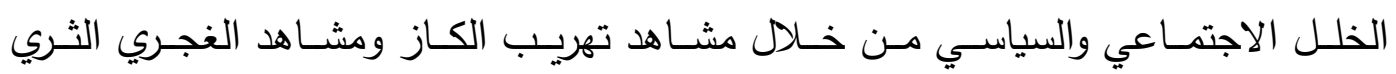

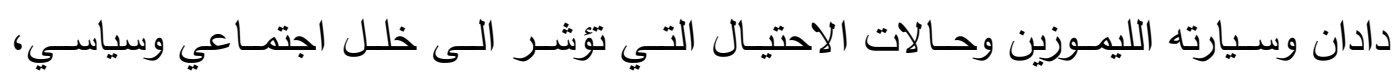

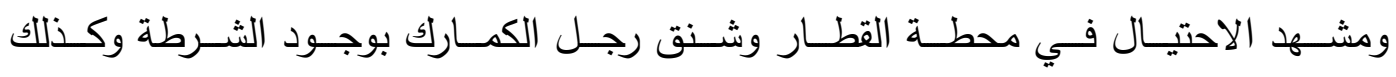

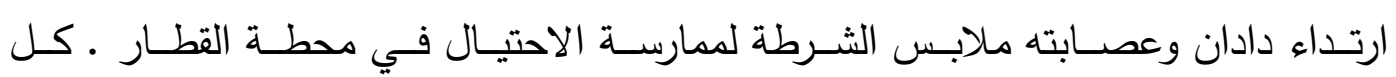
المشاهد تقدم بجو من السخرية والكوميديا. 
ع- يقدم الفيلم الاحتفـالي مزيجـا مـن الواقـع والعلـم والفنطازيـا ضـمن مـؤثرات الواقعيـة السحرية

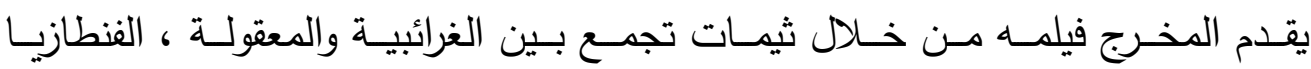

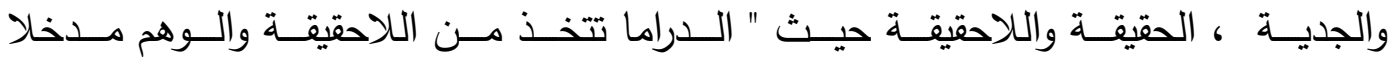

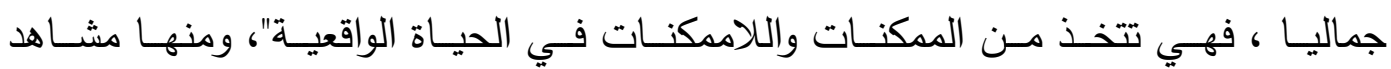

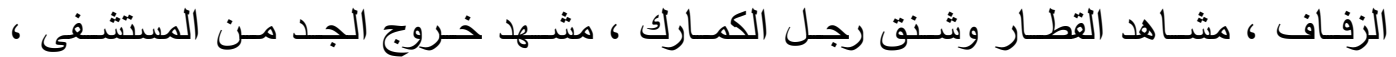

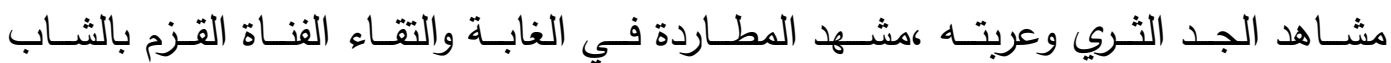

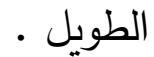

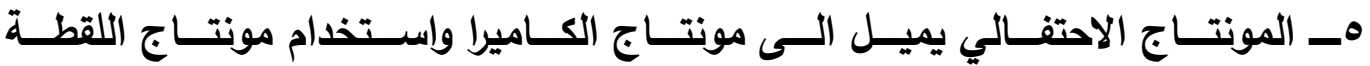

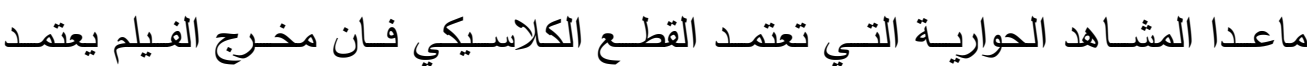
على الكـاميرا المتحركـة والمتابعـة للاحتفاليـة الفيلميـة حيـث يـتم المونتـاج مسن خـلاد

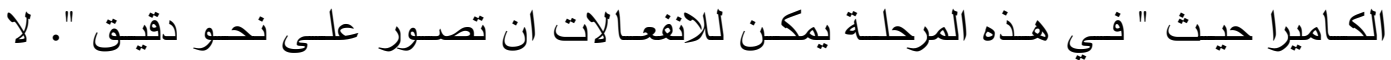

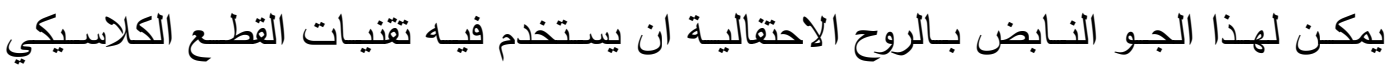

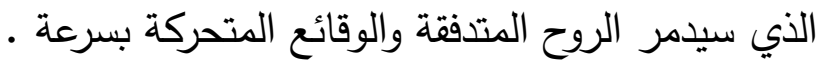
الفصل الخامس نتائج البحث النتائج

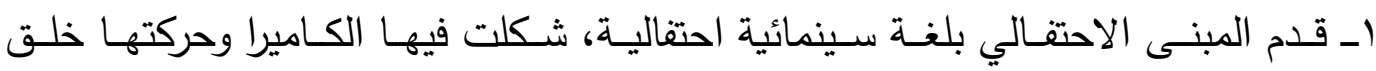

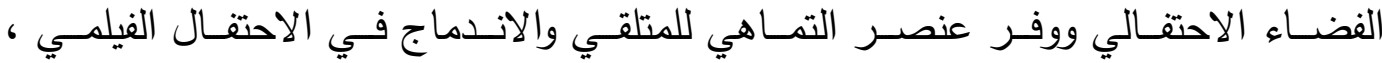

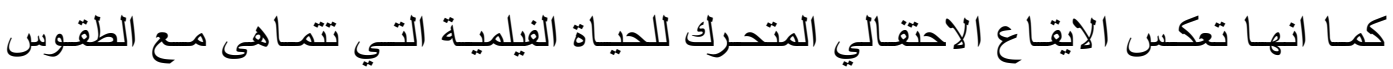
الاحتفالية النابضة بالحيوية والحركة المتدفقة.

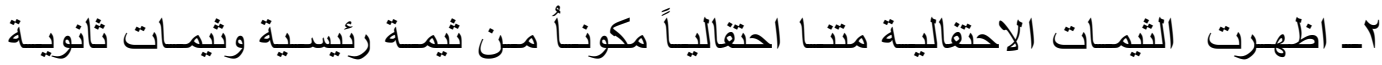
فاعتمـــ الفيلم تقديم الثيمـات الرئيسـية الخمس وثيمـات اخـرى ثانويـة ممـا يجعـل الفيلم

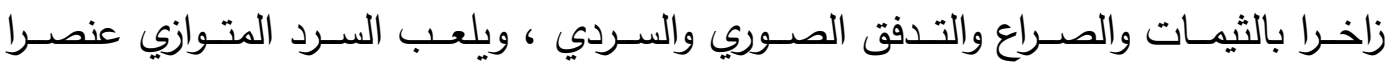

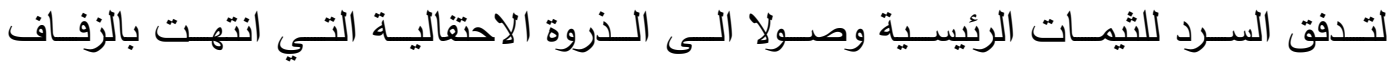

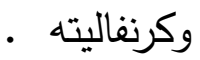

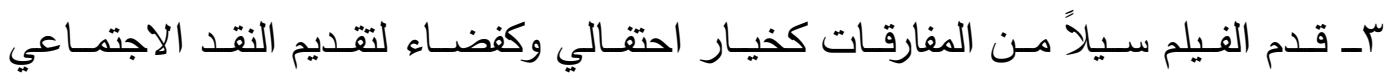

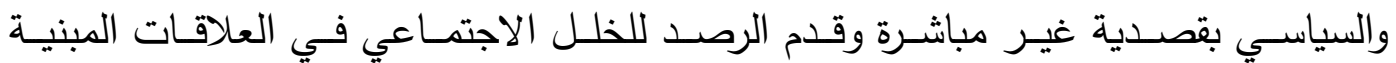

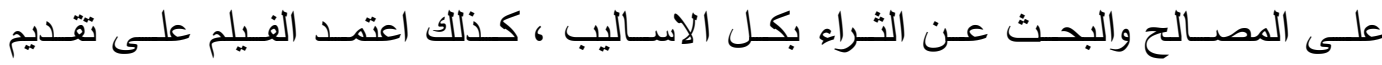

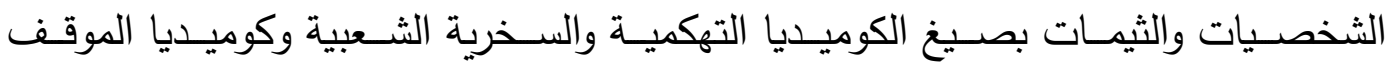




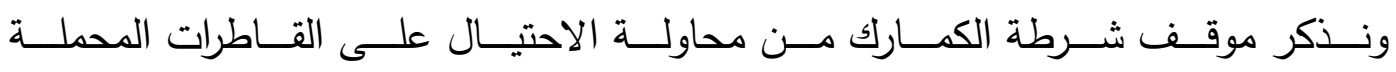
بالششتقات النفطية او الرشاوى في المستثفى.

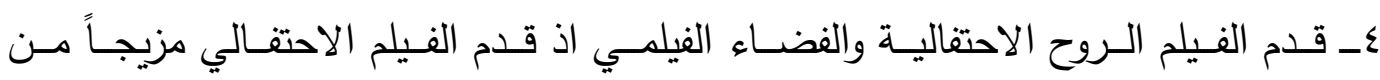

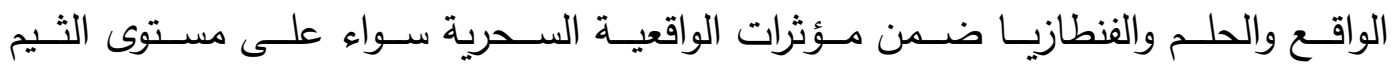

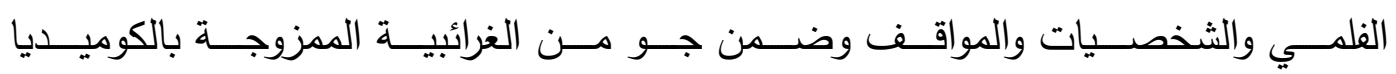
الفنطازية وصولا الى الملابس والحفلات .

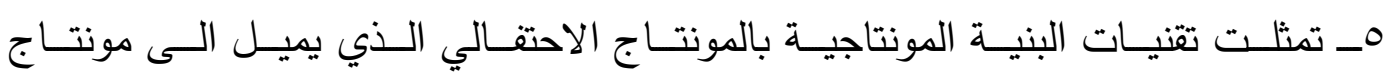

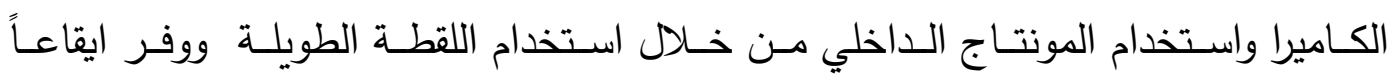

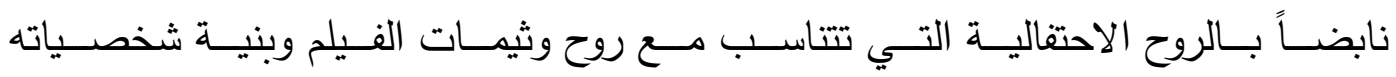

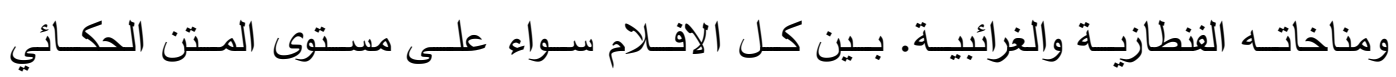

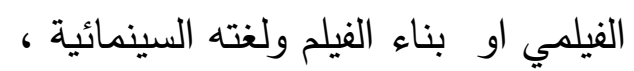

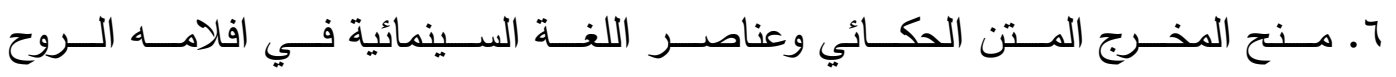

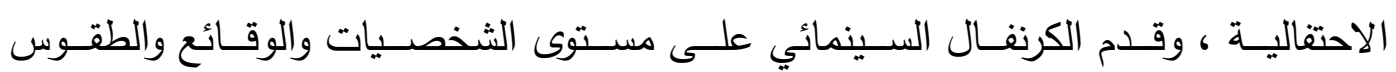

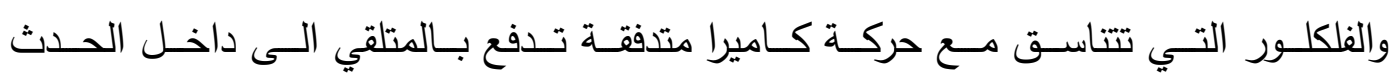

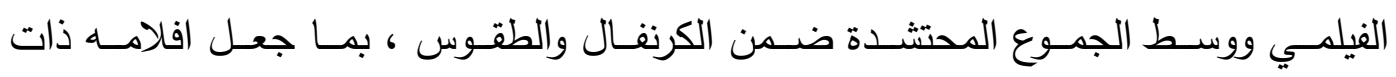

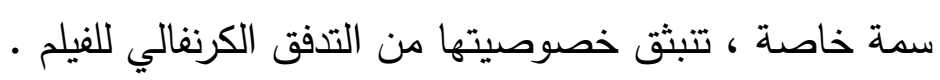
الاستنتاجات ا اكان لعناصر اللغة الصورية الاثر الكبير لإبراز ملامح الفلم الاحتفالي.

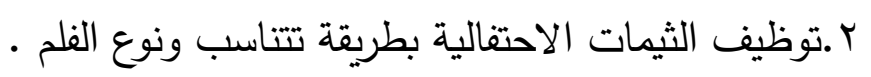

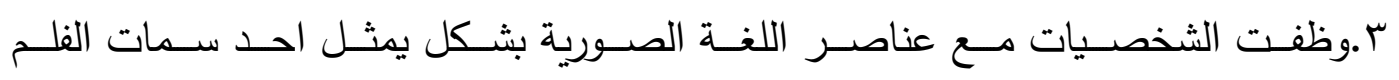
الاحتفالي. قائمة المصادر والمراجع الماني

ا. ابن منظور أبو الفضل جمال الدين، لسان العرب، تحقيق عامر أحمد حيدر،

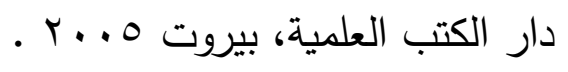

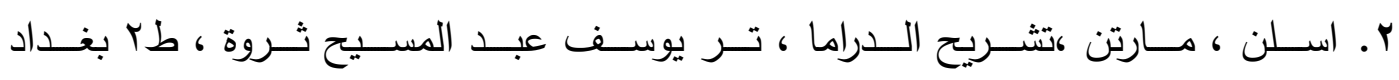
$.191 \leq$

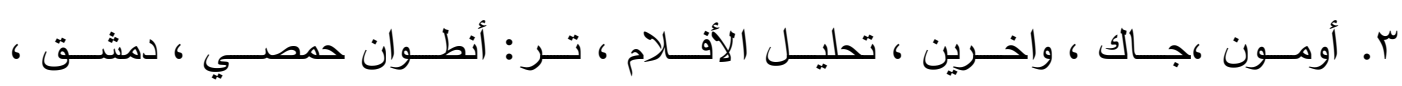

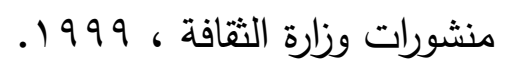

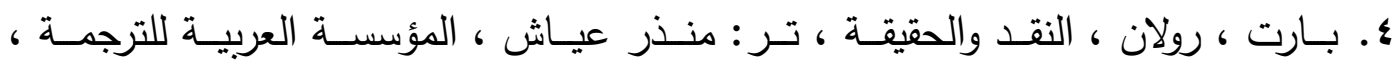

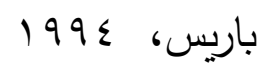




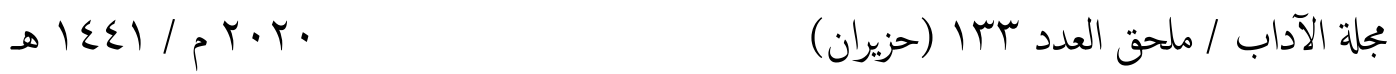

ه. بـوجز ، جوزيـف . م ، فـن الفرجـة ، تـر : وداد عبـد الله ، العيأــة المصـرية العامـة لـ ألكتاب ، القاهرة ، 1990

7. جـاكوب ، لـويس ، الوسـيط السـينمائي ،تـر : ابيـة حمـزاوي، المؤسســة العامـة للسـينما

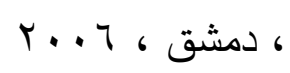

V. جـانيتي ، لــوي ،دي ، فهـم السـينما ، تـر : جعفـر علـي ، دار الرشـيد ، بغــداد ، 1911

^. ريكور ، بول ، الزمان والسرد ، ج) ،تر : سعيد الغانمي وفلاح رحيم. . . . . . 9 ـ الزين ،حمح شوقي ،تأويلات وتفكيكات، المركز الثقافي العربي، الدار البيضاء / ل

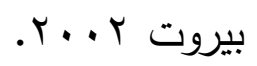

• ا. عبـد الواحـــ ،علـي، الـوافي ، الادب اليونـاني القـديم ، دار المعــارف ، مصـر .197.

ا ا. غـادامير، هـ.ج. ، الحقيقـة والمـنهج ، تـر : حسـن نـاظم و علـي حساكم ،دار

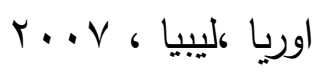

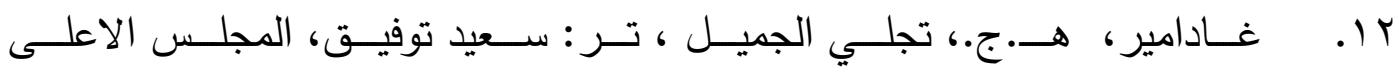

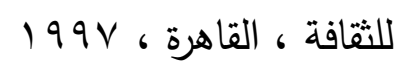

س ا. قـارة ، نبيهـــة ،الفلسـفة والتاويـلـ ، دار الطليعــة للطباعــة والنشــر ، بيـروت .1911

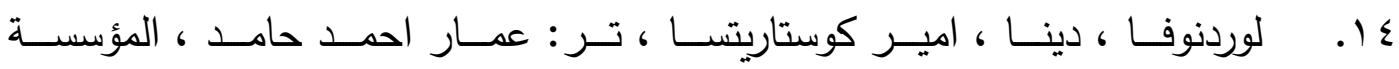

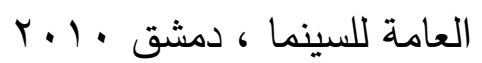

10. مصطفى إبراهيم وآخرون، المعجم الوسيط، المكتبة الإسـلامية، تركيا، . . . .

ج ا. اليـاس ، مــاري ،وحنــان قصــاب، المعجـم المسـرحي، مكتبــة لبنــان ، لبنــان، $.199 \mathrm{~V}$

البحوث المنشورة على الانترنيت

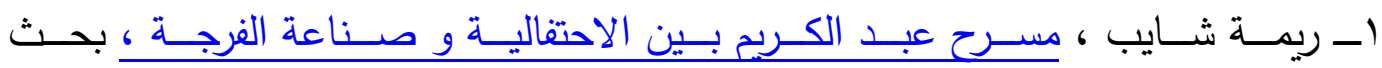
ماجستير منشور على الانترنيت

http://biblio.univ-annaba.dz/wpcontent/uploads/2014/07/\%D8\%B4\%D8\%A7\%D9\%8A\%D8\% A8-\%D8\%B1\%D9\%8A\%D9\%85\%D8\%A9.pdf 
List of sources and references

1. Ibn Manzoor Abu Al-Fadl Jamal Al-Din, Lisan Al-Arab, Investigation of Amer Ahmed Haider, Dar Al-Kutub AlAlami, Beirut 2005

2. Aslan, Martin, Anatomy of Drama, Ter Youssef AbdelMessih Tharwa, 2nd Baghdad, 1984.

3. Omon, Jack, and others, Film Analysis, Ter: Antoine Homsi, Damascus, Ministry of Culture Publications, 1999.

4. Bart, Roland, Criticism and Truth, Tert: Munther Ayyash, Arab Organization for Translation, Paris, 1994

5. Boggs, Joseph. M., The Art of Farjah, Ter: Wedad Abdullah, The Egyptian General Book Authority, Cairo, 1995

6. Jacob, Lewis, Film Mediator, Ter: Abaya Hamzawy, General Film Foundation, Damascus, 2006

7. Janetti, Lowe, D., Understanding Cinema, $\mathrm{T}$.: Ja`far Ali, Dar Al-Rashid, Baghdad, 1981

8. Ricoeur, Paul, Time and Narration, Part 1, T .: Saeed AlGhanmi and Falah Rahim. 2005.

9. Al-Zein, Mohamed Shawky, Interpretations and Decompositions, The Arab Cultural Center, Casablanca / Beirut 2002.

10. Abdel Wahid, Ali, Al-Wafi, Ancient Greek Literature, Dar Al-Maarif, Egypt 1960.

11. Gadamir, H.J. Truth and Approach, see: Hassan Nazem and Ali Hakem, Uriah House, Libya, 2007

12. Gadamir, HJ, Tajalli Al-Jameel, Ter: Saeed Tawfiq, The Supreme Council of Culture, Cairo, 1997.

13. Qara, Nabiha, Philosophy and Interpretation, Dar AlTale'ah for Printing and Publishing, Beirut 1988.

14. Lordova, Dina, Emir of Costa Rica, Ter: Ammar Ahmed Hamid, General Film Foundation, Damascus 2010.

15. Mustafa Ibrahim and Others, The Intermediate Dictionary, Islamic Library, Turkey, 2000.

16. Elias, Mary, and Hanan Kassab, The Theatrical Lexicon, Lebanon Library, Lebanon, 1997. 


\section{Festive movie features}

\section{Abstract:}

The topic of the features of the festive movie was not raised previously, nor was it established and prepared for it, therefore there is a precedent and difficulty in establishing and elaborating the features of this type of film, especially in the works of Prince of Costa Rica that have common features that we can call festive, which are different from the storytelling or watching. Or carnival, although all of these designations extend their roots to the ceremonial rituals of the peoples, which were embodied in the (Akito) ceremonies of the Babylonians, and the Greeks in the celebrations of Bakhos, as well as associated with rituals and festivals, which later turned to include festivals and worldly ceremonies. From its inception in the Greek incubator, the theater presented patterns of ceremonialness in the theater, specifically its first beginnings with the choir, and then the emergence of the single actor alternating with the choir. There is also the name of the ceremonial theater. But in the cinema, which is the most recent history of the theater that is deeply rooted in history, many directors have presented films bearing the characteristics of celebration, storytelling, spectacle and carnival. 